\title{
Functional Analysis of $\beta 1,3-N$-Acetylglucosaminyltransferases and Regulation of Immunological Function by Polylactosamine
}

\author{
及1,3-N-アセチルグルコサミン転移酵素の機能解析と \\ ポリラクトサミン糖鎖による免疫機能調節
}

\author{
Togayachi, Akira; and Narimatsu, Hisashi \\ Functional Glycoproteomics Team, Research Center for Medical Glycoscience (RCMG), National Institute of Advanced \\ Industrial Science and Technology (AIST), Central-2 OSL, 1-1-1 Umezono, Tsukuba, Ibaraki 305-8568, Japan \\ FAX: 81-29-861-3201, E-mail: a.togayachi@aist.go.jp
}

(Received on April 4, 2012, accepted on April 16, 2012)

Key Words: glycogene, glycosyltransferase, polylactosamine, beta-1,3-N-acetylglucosaminyltransferase, immunological function

\begin{abstract}
We have cloned many genes of $\beta 1$,3-glycosyltransferases, which transfer sugars via a $\beta 1,3$-linkage, and have characterized their biological functions. Among $\beta 1,3-$ glycosyltransferases, $\beta 1,3-N$-acetylglucosaminyltransferases $(\beta 3 \mathrm{GnTs})$ synthesize a unique carbohydrate structure known as "polylactosamine (poly- $N$-acetyllactosamine)". Polylactosamine is carried on $N$ - and $O$-glycans, and on glycolipids. Polylactosamine structures are considered to be integral components serving as a fundamental structure and backbone for carbohydrate structures. However, most of their biological functions are still unknown. To investigate the in vivo function of polylactosamine on glycoconjugates, we generated and analyzed two mouse lines of $\beta 1,3-N$ acetylglucosaminyltransferase (B3gnt)-deficient (B3gnt $2^{-/-}$or $B 3 g n t 5^{-/}$) mice lacking the polylactosamine structure.

First, to investigate the in vivo function of polylactosamine on glycoproteins, we analyzed gene knockout mice lacking $B 3 g n t 2$, which synthesizes polylactosamine on glycoproteins. In B3gnt $2^{-/}$mice, glycan analysis demonstrated that the amount of long polylactosamine chains on $N$-glycan was greatly reduced in the tissues of $B 3$ gnt $^{-\digamma}$ mice. We also examined immunological responses in B3gnt $2^{-\digamma}$ mice. B3gnt2 $2^{--}$ lymphocytes showed hyperactivation via TCR/CD28 or BCR stimulation.

Next, to investigate the in vivo function of polylactosamine on glycosphingolipids (glycolipid), we analyzed $B 3 g n t 5^{-1}$ mice lacking lacto/neolacto-series glycolipids. B3gnt $5^{-1-}$ B cells showed an abnormality of glycolipid-enriched microdomains (GEMs; also known as glycolipid rafts) and showed hyperactivation via BCR-related molecules in GEMs, as compared with wild-type (WT) B cells.
\end{abstract}

Polylactosamine deficiency seems to be involved in
要 約

我々は、 $\beta 1,3$-結合で糖を転移する糖転移酵素群に属する 多数の遺伝子の単離と機能解析を進めてきた。これらの $\beta 1,3-$ 結合糖転移酵素のうち、 $\beta 1,3-N$-アセチルグルコサミン転移酵 素群は「ポリラクトサミン(polylactosamine、正式にはポリ-Nアセチルラクトサミン: poly- $N$-acetyllactosamine と称する)」 と呼ばれる特徵的な糖鎖構造を合成する。このポリラクトサ ミン糖鎖構造は糖タンパク質 $(O$-glycan、 $N$-glycan $)$ や糖脂質 上に存在している。ポリラクトサミン糖鎖は、糖鎖の基幹的 な構造を形成しており、非常に重要な構造のひとつであると 考えられている。しかしながら、その生体内に扔ける機能は あまりよく分かっていない。そこで、我々はポリラクトサミ ン鎖合成に関与する $\beta 1,3-N$-アセチルグルコサミン転移酵素の うち、2つの酵素の遺伝子ノックアウトマウス (B3gnt2\% マ兵 ス、B3gnt5 -マウス) を作製し、その表現型を中心に解析を行 うこととした。

まず、糖タンパク質上のポリラクトサミンの生体内機能 を解析するために、糖タンパク質上のポリラクトサミンの 合成に関与する、 $\beta 1,3-N$ - アセチルグルコサミン転移酵素 2 (B3gnt2) 遺伝子ノックアウト $\left(B 3 g n t 2^{-/}\right)$マウスを解析した結 果、このBggnt2 マウスでは糖タンパク質の $N$-glycan 上の長 鎖ポリラクトサミン構造が有意に減少して抢り、B Bgnt2-・リ ンパ球では TCR/CD28 分子あるいは BCR 分子を介した免疫 活性化の克進を起こしていた。

次に、糖脂質上のポリラクトサミンの生体内機能を解析 するために、ラクト/ネオラクト系列糖脂質が欠損している、 B1,3- $N$ - アセチルグルコサミン転移酵素 5 (B3gnt5) 遺伝子ノッ クアウト (B3gnt5 ) マウスを用いて解析を行った。B マウス由来 B 細胞では、糖脂質マイクロドメイン構造 (GEM: glycosphingolipids-enriched microdomain あるいは糖脂質ラフ 卜構造とも言われている)の形成異常が観察され、B B gnt $t 5$ - B 細胞では野生型マウスに比較して GEM 構造内の BCR 関連分 子を介した免疫反応性の充進が確認された。 
the immunological disorders observed in these mice. Taken together, these studies suggest that the polylactosamine chain is a putative immune regulatory factor that presumably suppresses excessive responses during immune reactions and has an important biological role in the immune system.

\section{A . Introduction}

Polylactosamine-containing repeats of the $\mathrm{N}$-acetyllactosamine (LacNAc) unit (Gal[galactose] $\beta 1-4 \mathrm{GlcNAc}[N$-acetylglucosamine $] \beta 1-3) \mathrm{n}$ represent a fundamental structure of glycans carried on $N$-, and $O$-glycans, as well as on glycosphingolipids (glycolipids) (13) (Fig. 1A). Polylactosamine is coordinately synthesized by the alternative action of a $\beta 1,4$-galactosyltransferase ( $\beta 4 \mathrm{GalT})$ and a $\beta 1,3-N$-acetylglucosaminyltransferase ( $\beta 3 \mathrm{GnT})(4)$. It is considered that polylactosamine chains form an important scaffold that serves as a backbone for the carbohydrate structures.

The human blood group i antigen structure and I antigen structure have been characterized as linear and ß1-6-branching polylactosamine structures, respectively (5, 6). It is also known that polylactosamine functions as a ligand for some endogenous lectins such as galectins (7). This indicates that the polylactosamine structure is a biofunctional carbohydrate structure. Furthermore, polylactosamine chains are further modified by the addition of different carbohydrate antigens such as Lewis blood group antigens, including Lewis $\mathrm{x}$ (Le ${ }^{\mathrm{x}}$, CD15, SSEA-1) antigen, HNK-1 (CD57) antigen, and keratan sulfate, which is a glycosaminoglycan containing sulfated polylactosamine. Therefore, it seems that polylactosamine plays many roles in biological processes by bearing various functional carbohydrate antigens on its structure.

For example, it is well known that sialyl Lewis $\mathrm{x}$ $\left(\mathrm{sLe}^{\mathrm{x}}, \mathrm{CD} 15 \mathrm{~s}\right)$ antigens exist on the non-reducing end of polylactosamine structures. $\mathrm{sLe}^{\mathrm{x}}$ structure functions as a ligand for adhesion molecules such as selectin on lymphocyte homing. sLe ${ }^{\mathrm{x}}$ antigen is an important structure for lymphocyte accumulation and infiltration to inflammation sites (8-11). This suggested that the polylactosamine structure might be related to lymphocyte homing. In addition, the length of the polylactosamine chain is also an important factor in immune responses. Polylactosamine inhibits NK cell-mediated cytotoxicity during binding to the target cell (12). On the other hand, it is considered that $\mathrm{sLe}^{\mathrm{x}}$ on polylactosamine and the length of the polylactosamine chain is related to malignancy (cancer metastasis). In cancer metastasis, both highly and poorly metastatic tumor cells derived from the same patient were found to express almost the same amount of $\operatorname{sLe}^{\mathrm{x}}$ antigens, regardless of different metastatic ability.
ポリラクトサミン糖鎖の欠損がこれらのマウスで観察さ れた免疫異常を及ぼしているようである。本研究により、ポ リラクトサミン糖鎖が過剩な免疫反応に抑制的に働いている ことが示唆され、ポリラクトサミン糖鎖が免疫システムにお いて重要な機能を担っていることが明らかになった。

\section{A. はじめに}

ポリラクトサミン糖鎖構造はガラクトース (Gal) と N-ア セチルグルコサミン (GlcNAc) が $\beta 1,4$ - 結合した $N$ - アセチ ルラクトサミン (Gal $\beta 1-4 \mathrm{GlcNAc} \beta 1-3)$ を1 ユニットとする 繰り返し構造をとり、糖タンパク質 $(N$-glycan、O-glycan) あるいは糖脂質上などに存在する (1-3) (図 1A)。ポリ ラクトサミン構造は、 $\beta 1,4-$ ガラクトース転移酵素 ( $\beta 1,4-$ galactosyltransferase) と $\beta 1,3-N$ - アセチルグルコサミン転移酵 素 ( $\beta 1,3-N$-acetylglucosaminyltransferase) とが交互に糖を転移 する協調的な働きにより生合成される (4)。多くの糖鎖構造の 中でも、ポリラクトサミン糖鎖構造は、糖鎖の基幹的な構造 を形成するものとして、非常に重要であると考えられている。

ポリラクトサミンは血液型 (Ii 式) 関連糖鎖である $\mathrm{i}$ 抗原 としても知られ、GlcNAc 糖残基で $\beta 1,6$ - 分岐した構造を有す る場合には I 抗原と呼ばれる $(5 、 6)$ 。ポリラクトサミンの構 造自体が、ガレクチン (Galectin) のような内在性レクチンの リガンドとして機能 (7) することから、ポリラクトサミン構造 は機能糖のひとつであると言える。また、ポリラクトサミン 糖鎖の構造上やその非還元末端には、ルイス $\mathrm{x}$ (Lewis $\mathrm{x}$ : Le CD15、SSEA-1) 抗原などのルイス式血液型関連糖鎖抗原 (6365)、HNK-1 抗原 (CD57 抗原) (27-29)、ポリラクトサミン糖鎖 を母核としたグリコサミノグリカンであるケラタン硫酸糖鎖 構造などが形成されることが知られている。従って、ポリラ クトサミンは様々な機能性糖鎖構造を担うことで、種々の生 命現象に関与するようである。

例えば、ポリラクトサミンの非還元末端にはシアリルル イス $\mathrm{x}$ 糖鎖抗原が存在することは良く知られている。シアリ ルルイス $\mathrm{x}$ (sialyl Lewis $\mathrm{x}$ : $\mathrm{sLe}^{\mathrm{x}} 、 \mathrm{CD} 15 \mathrm{~s}$ ) 抗原は、接着分子 セレクチンのリガンドとして血球細胞のホーミング時に作用 する糖鎖構造で、血球細胞の炎症部位への集積、浸潤に必要

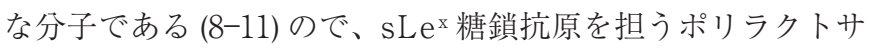
ミンも血球細胞のホーミングに関与すると考えることが出来 る。加えて、ポリラクトサミン鎖の長さは免疫反応に怙ける 重要な因子でもある。NK細胞の標的細胞の結合過程（認識 過程）に扔いて、ポリラクトサミンが NK 細胞の細胞障害活 性を抑制することも知られている(12)。また、このポリラク トサミン上の $\mathrm{sLe}$ 糖鎖抗原や、ポリラクトサミン糖鎖の長さ は、がんの悪性度（転移能）に関係していると考えられている。 例えば、同一患者由来の 2 つのがん細胞株では、それぞれ高 転移性株あるいは低転移性株として転移性が異なっていたが、 発現している $\mathrm{sLe}^{\mathrm{x}}$ 糖鎖抗原量はほぼ同じであった。しかしな がら、低転移性の細胞株では、より短いポリラクトサミン鎖 
However, $\mathrm{sLe}^{\mathrm{x}}$ in $\mathrm{N}$-glycans with a shorter polylactosamine chain is more abundant in poorly metastatic colon carcinoma cells (13). These results suggested that both polylactosamine structure and length might also be important in tumor malignancy and cell-cell interactions. Thus, it is thought that the polylactosamine structure has various biological functions, either direct or indirect.

At present, many biological functions of polylactosamine have been identified in vitro, but little is known of their functions in vivo and their molecular mechanisms.

\section{B. Cloning of a Set of $\beta 1,3-N$-Acetylglucosaminyltransferases Involved in Synthesis of Polylactosamine Chains}

The first cloned glycosyltransferase gene, $\beta 1,4-$ galactosyltransferase I ( $\beta 4 \mathrm{GalT} 1)$, was cloned and characterized by Narimatsu et al. in 1986 (14). Thereafter, many glycosyltransferase genes have been cloned by enzyme purification, expression cloning, searching for homologous genes by Southern Blot analysis, and PCR cloning with degenerate primers. In addition, the biological functions of glycosyltransferases have been characterized. As a consequence of recent improvements in database construction and bioinformatics technology, in silico cloning of glycosyltransferase genes has become the mainstream technique. Currently, over 186 kinds of glycosyltransferase gene have been isolated and characterized by many laboratories. As a result, it has been found that the glycosyltransferase genes form several subfamilies, and that the amino acid sequences in these subfamilies contain wellconserved motifs. It is known that glycosyltransferases have some specificity. The properties conserved in each subfamily reflect their enzymatic character as follows: (1) donor specificity, (2) acceptor specificity (sequence of carbohydrate chains), and (3) anomer specificity (specificity for anomeric bond; i.e., the specific linkage between donor and acceptor).

As described above, gene cloning by database (in silico) searching has become mainstream in recent years. Our group and many others have been pursuing the cloning of a novel set of glycosyltransferase genes belonging to the $\beta 3$ glycosyltransferase family by searching for a unique sequence specific to $\beta 3$-glycosyltransferase (especially the $\beta 3 \mathrm{GT}$ motif, Fig. 1B) (15-21).

At present, the $\beta 1,3$-galactosyltransferase ( $\beta 3 \mathrm{GalT})$, $\beta 1,3-N$-acetylgalactosaminyltransferase ( $\beta 3 \mathrm{GalNAcT}$ ), and $\beta 3 \mathrm{GnT}$ groups that have been isolated and reported to date are known form a gene family with a shared (" $\beta 3 \mathrm{GT}$ ") motif (Fig. 1C). The accession numbers of these $\beta 3 \mathrm{GT}$ genes and their products are shown in Table I. In addition, a previous
の上の $\mathrm{sLe} \mathrm{e}^{\mathrm{x}}$ 糖鎖抗原量が多かった、との報告がある (13)。

以上のように、シアリルルイス抗原を担うポリラクトサ ミン自体の構造やその長さは、がんの悪性度や細胞間相互作 用において重要であることが示唆されている。このようにポ リラクトサミン糖鎖は直接的あるいは間接的に様々な生物機 能を有していると考えられる。

しかし、現在までのところ、ポリラクトサミンの機能は in vitroでの解析により同定されたものが多く、ポリラクトサ ミンの生体内 (in vivo) での生物機能やその分子メカニズムは 未た、十分には解明されていない。

B. ポリラクトサミン糖鎖の合成に関与する糖転移酵素、 $\beta 1,3-N$ - アセチルグルコサミン転移酵素遺伝子群のクローニ ング

1986 年に成松らによって初めて糖転移酵素・ $\beta 1,4-$ ガラク トース転移酵素 I ( $\beta 4 \mathrm{GalT} 1)$ の遺伝子がクローニング、解析さ れた(14)。その後、現在までに酵素の精製、発現クローニン グ法、サザンブロッティング法などによる類似遺伝子の探索、 degenerate primerによるPCRクローニング法などにより多 くの糖転移酵素遺伝子がクローニングされ、それらの機能の 解析がなされてきた。また近年、各種データベースの構築 · 拡充とバイオインフォマティクスにより、in silico での糖転移 酵素遺伝子の探索が遺伝子発見のメインストリームとなって いる。その結果、多くの研究グループにより、現在では 186 種類以上の糖転移酵素遺伝子が単離、解析されている。また、 その結果から、糖転移酵素遺伝子が幾つかの subfamily を形 成することが分かってきた。これらの subfamilyごとに、そ のアミノ酸配列上よく保存された motif などが存在すること が分かってきている。糖転移酵素は以下に挙げる基質特異性 を有するが、subfamily ごとに保存された特徴は、これらの特 異性を反映しているのではないかと考えられる。(1) 供与体に 対する基質特異性、(2) 受容体基質に対する特異性（受容体糖 鎖の糖鎖配列)、(3) アノマー (anomer) に対する特異性 (アノ メリック結合。ドナーとアクセプター間の結合様式)、である。

上記のように、近年はデータベース (in silico) による遺伝 子の探索による遺伝子クローニングが主流になっている。我々 のグループを始め、多くの研究グループにより、in silicoで $\beta 1,3-$ 結合糖転移酵素に特徵的な配列 (特に $\beta 3 \mathrm{GT}$ モチーフ。 図 1B) を探索することで、その subfamily に属する新規の糖 転移酵素遺伝子群がクローニングされ、解析が進められてき た(15-21)。

その結果、現在までのところ、 $\beta 3 \mathrm{GalT}$ 、 $\beta 3 \mathrm{GalNAcT}$ 、 $\beta 3 \mathrm{GnT}$ 群により、共通のモチーフ配列 (B3GT モチーフ)を有 する遺伝子ファミリーを形成していることが明らかとなって いる (図 $1 C)$ 。各 $\beta 1,3$ - 結合糖転移酵素の遺伝子などのアクセッ ション番号のほか、合成する糖鎖構造を表Iに示しておく。 
review has explained the gene cloning and detailed substrate specificity of these enzymes (22).

Regarding the cloning of $\beta 3 \mathrm{GnT}$ enzymes involved in polylactosamine synthesis, iGnT ( $\beta 3 \mathrm{GnT} 1)$ was the first $\beta 3 \mathrm{GnT}$ to be isolated (19). Thereafter, a set of $\beta 3 \mathrm{GnT}$ genes,
これらの遺伝子クローニングや基質特異性などについて の詳細は過去の別稿 $(22)$ にて紹介しているので、参考にして 頂きたい。

ポリラクトサミン糖鎖の合成に関与する $N$ - アセチルグル コサミン転移酵素では、始めにiGnT ( $\beta 3 \mathrm{GnT} 1)$ がクローニン

\section{A Polylactosamine Structure}

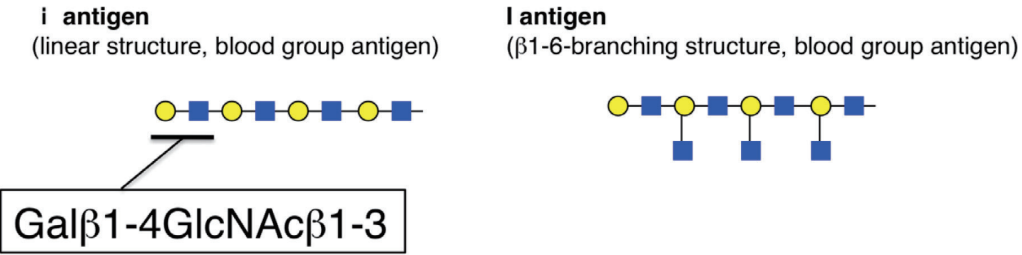

B Amino acid sequences in these $\beta 3 G T$ s (subfamily) contain well-conserved " $\beta 3 G T$ " motifs.

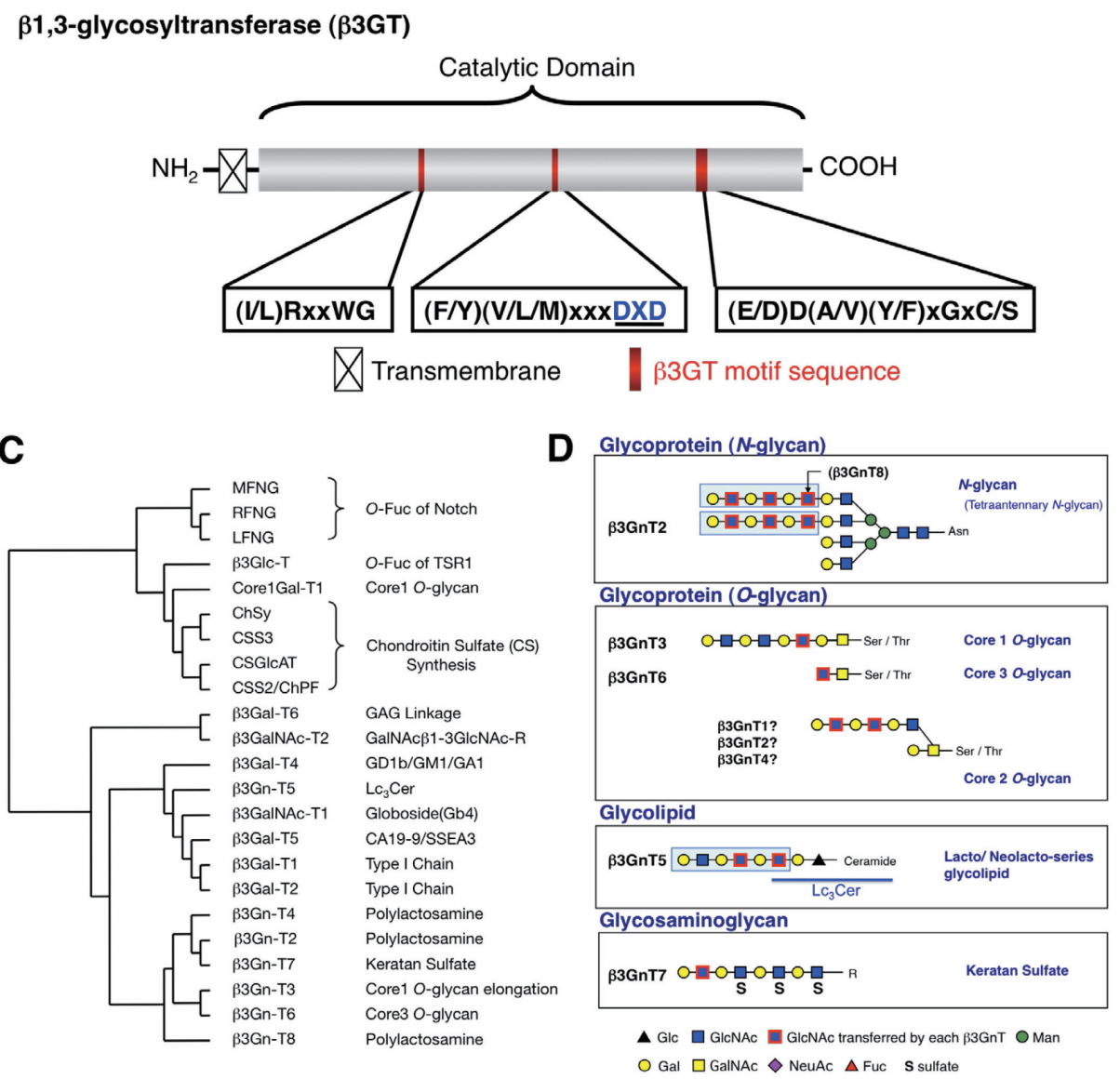

Fig. 1. Polylactosamine structure and subfamily of $\beta 1,3$-glycosyltransferase ( $\beta 3 G T)$ genes. (A) Illustration of the polylactosamine structure, which consists of $N$-acetyllactosamine (Gal $\beta 1-4 \mathrm{GlcNAc}$ : LacNAc) repeats. The linear polylactosamine structure is also known as a blood group antigen, $\mathrm{i}$ antigen. The $\beta 1-6$-branching polylactosamine structure is also known as a blood group antigen, I antigen. (B) The amino acid sequences in the $\beta 3 \mathrm{GT}$ subfamily contain well-conserved " $\beta 3 \mathrm{GT}$ " motifs. Glycosyltransferase genes of the $\beta 3 \mathrm{GT}$ family contain three conserved $\beta 3 \mathrm{GT}$ motifs in their amino acid sequence. In the $\beta 3 \mathrm{GT}$ motif, the DXD sequence that is essential for divalent cation binding is underlined. (C) Phylogenetic tree of human $\beta 3 \mathrm{GTs}$ constructed by ClustalW on the basis of amino acid sequence. The reaction products of each enzyme are shown on the right. (D) Carbohydrate structures containing polylactosamine chains. Representative glycan structures are synthesized by each $\beta 3 \mathrm{GnT}$. Predicted carbohydrate structures (epitope recognized by LEL) that are possibly lacking in B3gnt $2^{-/}$mice or B3gnt $5^{-/-}$mice are indicated by rectangles. 


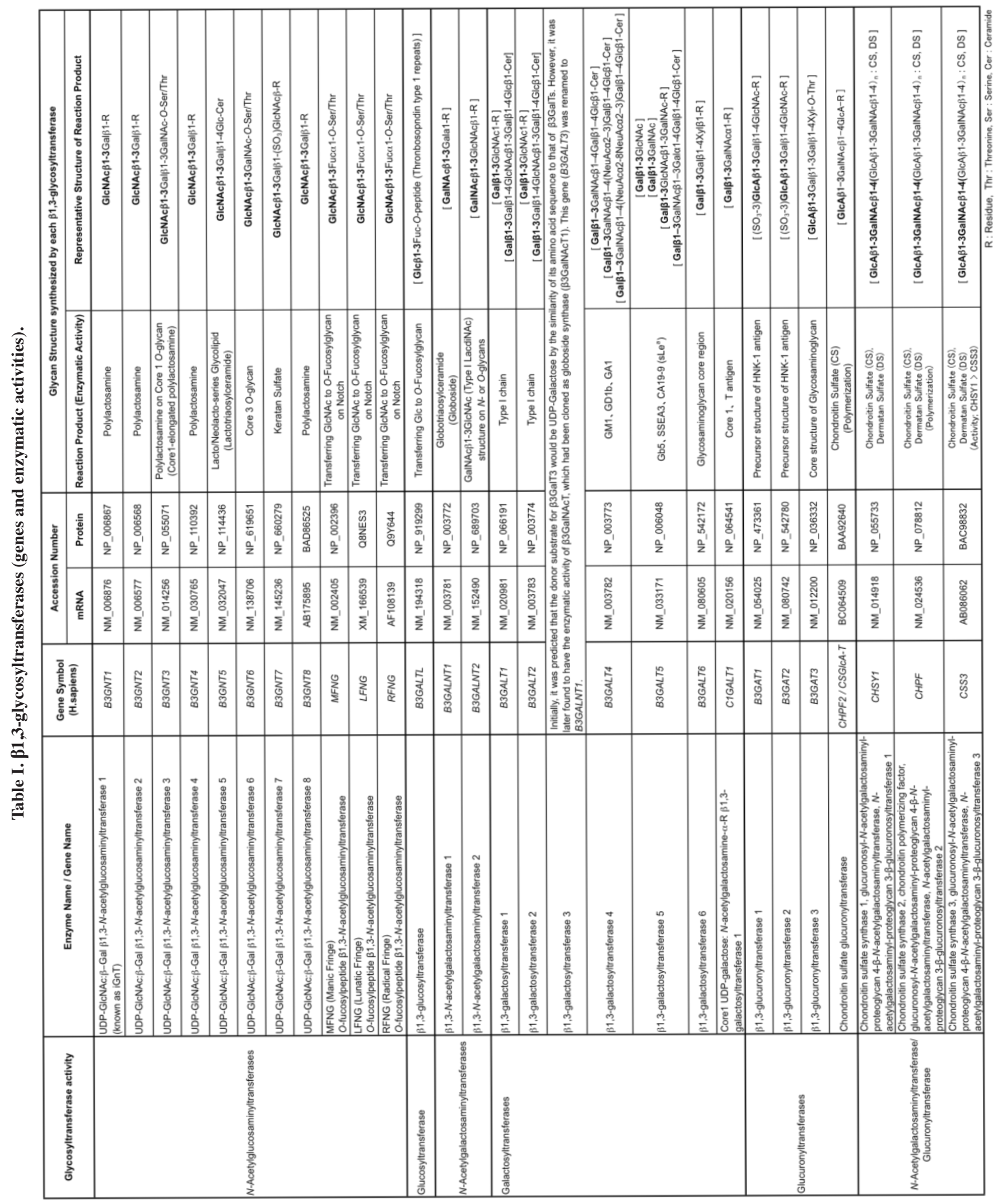


having sequences similar to those of $\beta 3 \mathrm{GalTs}$, has been isolated effectively using in silico bioinformatics analysis $(20,21)$. Recently, it was reported that $\beta 3 \mathrm{GnT} 1$ is involved in the synthesis of glycan on $\alpha$-dystroglycan, and affects tumor progression (23). Regarding enzymatic activity toward oligosaccharide substrates, $\beta 3 \mathrm{GnT} 2$ had clearly stronger activity in vitro on oligosaccharide substrates with polylactosamine structures, suggesting that it is the main polylactosamine synthase $(21,24)$. Yeh et al. reported that $\beta 3 \mathrm{GnT} 3$ is an enzyme that further elongates the core 1 $O$-glycan structure (25). $\beta 3 \mathrm{GnT} 4$ has weak polylactosamine synthetase activity. However, much of the $\beta 3 \mathrm{GnT} 4$ substrate specificity is unclear.

Lactotriaosylceramide $\left(\mathrm{Lc}_{3} \mathrm{Cer}\right)$ is a precursor structure for lacto/neolacto-series glycolipid and polylactosamine chains elongated on $\mathrm{Lc}_{3} \mathrm{Cer}$. $\beta 3 \mathrm{GnT} 5$ has been isolated as $\mathrm{Lc}_{3} \mathrm{Cer}$ synthase $(24,26)$. Expression of the HNK-1 and $\mathrm{Le}^{\mathrm{x}}$ antigens on the lacto/neolacto-series of glycolipids has been shown to be developmentally and tissue-specifically regulated by $\beta 3$ GnT5 (synthesizing the lacto/neolacto-series of glycolipids), and this enzyme appears to be closely involved in important functions such as intercellular recognition for the extension of neurons and others $(24,27-29)$. It has been reported that the $\beta 3 \mathrm{GnT} 6$ is an enzyme that synthesizes the core $3 \mathrm{O}$-glycan structure (30). We speculate that this enzyme plays an important role in the synthesis and function of mucin $O$-glycan in the digestive organs.

Gene expression of $\beta 3 \mathrm{GnT} 7$ has been reported to be downregulated upon malignant transformation (31), and is known (to some groups) to synthesize the polylactosamine structure in the cell. Seko et al. have recently shown that $\beta 3 \mathrm{GnT7}$ exhibits activity for transferring GlcNAc to $\mathrm{Gal} \beta 1 \rightarrow 4\left(\mathrm{SO}_{3}^{-} \rightarrow 6\right) \mathrm{GlcNAc} \beta 1 \rightarrow 3 \mathrm{Gal} \beta 1 \rightarrow 4\left(\mathrm{SO}_{3}^{-} \rightarrow 6\right)$ GlcNAc (L2L2 oligosaccharide) of keratan sulfate (32). $\beta 3 \mathrm{GnT} 8$ transfers GlcNAc to the non-reducing terminus of the Gal $\beta 1-4$ GlcNAc of tetraantennary $N$-glycan (33). Furthermore, it has been reported that $\beta 3 \mathrm{GnT} 8$ and $\beta 3 \mathrm{GnT} 2$ can form a hetrocomplex with enhanced enzymatic activity (34). It has been suggested that $\beta 3 \mathrm{GnT} 2$ and $\beta 3 \mathrm{GnT} 8$ are cooperatively involved in elongation of polylactosamine chains on multiantennary $\mathrm{N}$-glycans. The structure of the carbohydrate chain synthesized by each $\beta 3 \mathrm{GnT}$ is shown in Fig. 1D.

Thus, at present, various functional analyses using these cloned genes have been performed, as mentioned below, since the cloning of many genes has been successful. However, it has been unclear how these multiple $\beta 3 \mathrm{GnTs}$ differentially function in vivo. グされていたが(19)、その後、in silicoによるバイオインフォ マティクス解析を効果的に用いることにより、 $33 \mathrm{GalT}$ に類似 の配列を有する $\beta 3 \mathrm{GnT}$ 遺伝子群についても単離されてきた (20、21)。近年、 $\beta 3 \mathrm{Gn}-\mathrm{T} 1$ は $\alpha$ - ジストログリカン分子上の糖 鎖の合成に関与し、がんの進展に影響を与えることが明らか にされた (23)。ポリラクトサミン構造のオリゴ糖基質に対す る in vitroでの活性では、B3GnT2 が明らかに強い活性を示し ており、このことから $\beta 3 \mathrm{GnT} 2$ が主たるポリラクトサミン合 成酵素であると考えられた $(21 、 24) 。 \beta 3 G n T 3$ は Yeh らにより、 core 1 構造をさらに伸長させる酵素であるということが報告 された (25)。 $\beta 3 \mathrm{GnT} 4$ は弱いながらポリラクトサミン合成酵素 活性を有しているが、 $33 \mathrm{GnT} 4$ の詳細な基質特異性について は現在でもあまりょく分かっていない。

ポリラクトサミンが伸張するラクト・ネオラクト系列糖脂質 の前駆体糖脂質である、Lactotriaosylceramide $\left(\mathrm{Lc}_{3} \mathrm{Cer}\right)$ の合成酵 素遺伝子として $\beta 3 \mathrm{GnT} 5$ がクローニングされた $(24 、 26)$ 。ラク 卜・ネオラクト系糖脂質上の HNK-1 抗原や $\mathrm{Le}^{\mathrm{x}}$ 抗原は発生特 異的あるいは組織特異的にその発現が制御されており、細胞 間認識等を始めとした重要な機能により、神経細胞の伸長な どに関与していると思われるが、その発現調節はラクト・ネ

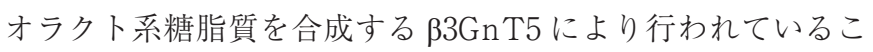
とが明らかになった (24、27-29)。また、B3GnT6がO-glycan の core 3 構造を合成する酵素であるということが報告された (30)。この酵素は消化器官におけるムチン上の $O$-glycan の合 成と機能に重要な役割を担っていると考えられる。

B3Gn-T7 はがん化に扔いて遺伝子発現が下がるものと して報告がなされており(31)、一部のグループによって細胞 のポリラクトサミン構造を合成することは知られていたが、 その後、 $\beta 3 \mathrm{GnT} 7$ がケラタン硫酸の Gal $\beta 1 \rightarrow 4\left(\mathrm{SO}_{3^{-}} \rightarrow 6\right)$ $\mathrm{GlcNAc} \beta 1 \rightarrow 3 \mathrm{Gal} \beta 1 \rightarrow 4\left(\mathrm{SO}_{3^{-}} \rightarrow 6\right) \mathrm{GlcNAc}(\mathrm{L} 2 \mathrm{~L} 2$ オリゴ糖) にGlcNAc を転移する活性を有するということが明らかにさ れている (32)。 $\beta 3 \mathrm{GnT}$ T は 4 本鎖分岐の $N$-glycan にポリラク トサミン合成活性を示す (33)。その後、 $\beta 3 \mathrm{GnT} 8$ が $\beta 3 \mathrm{GnT} 2$ とのへテロな会合体を形成することで、そのポリラクトサミ ン合成活性が大幅に充進されるという報告がなされている (34)。 $\beta 3 \mathrm{GnT} 2$ と $\beta 3 \mathrm{GnT}$ \% は協調的に働き、多分岐の $N$-glycan 上のポリラクトサミン鎖の伸張を行っているものと考えられ る。以上のように、各 $\beta 3 \mathrm{GnT}$ 酵素は、それぞれ異なる糖鎖構 造を合成することが明らかとなってきている(図 1D)。

このように、多くの遺伝子がクローニングされてきたこ とにより、後述のような、遺伝子を使用した種々の機能解析 がなされるようになっている。しかしながら、これら複数の $\beta 3 \mathrm{GnT}$ 酵素が生体内でどのように使い分けられ、機能してい るのかはよく分かっていなかった。 


\section{Functional Analysis of Glycans Using Glycogene (Glycosyltransferase gene)-Deficient Mice}

At mentioned above, more than 186 kinds of glycosyltransferase gene have been cloned. Together with the identification of glycogenes, human diseases caused by abnormalities of glycogenes have become clear. For example, it has been clarified that many diseases such as Congenital Disorders of Glycosylation (CDG) and congenital muscle dystrophy (Muscle-Eye-Brain Disease and Walker-Warburg Syndrome) are caused by abnormalities of glycosyltransferase genes (35-39).

It is thought that glycan has an important role in biological functions. In the past, functional analysis of glycan was very difficult. By cloning and analyzing glycogenes, however, now we can generate glycogene-deficient mice and investigate the physiological function of a glycan, glycoprotein, and/or glycolipid in cell.

It is thought that polylactosamine is an important structure with various functions. It is still unclear what molecules carry the polylactosamine chain. In addition, the length of polylactosamine chains on various glycans is not known in detail.

Thus, some research groups have attempted to investigate the functions of polylactosamine by analyzing knockout mice lacking this molecule. For example, it has been reported that one knockout (B3gnt $2^{--}$) mouse strain lacking polylactosamine exhibits severely disorganized olfactory bulb innervation and defective glomerular formation, resulting in a functional sensory deficit. This suggests that polylactosaimine is required for synapse formation in olfactory bulb innervation (40).

In order to clarify the role and biological functions of polylactosamine chains on immunologically relevant sites, we have generated and analyzed two strains of B3gnt genedeficient mouse $(41,42)$, as outlined below.

\section{Analysis of an Immunological Disorder (Phenotype) in the B3gnt2-Deficient (B3gnt2 ${ }^{-/}$) Mouse}

First, we generated and analyzed B3gnt2-deficient (B3gnt2 ${ }^{-/}$) mice lacking $\beta 3 \mathrm{GnT} 2$, which is the major polylactosamine synthase (42). The number of (long) polylactosamine structures was markedly lower in $B 3 g n t 2^{-1-}$ mice than in WT mice. To detect polylactosamine structures in this study, we used a lectin, Lycopersicon esculentum (tomato) agglutinin (LEL), which is known to bind to polylactosamines with at least three repeated lactosamine units, as a probe (43, 44). Flow cytometry using LEL, LEL-blotting analysis and glycan analysis by metabolic labeling demonstrated that the amount of long polylactosamine chains on $\mathrm{N}$-glycans was greatly reduced in the tissues of B3gnt $2^{-/-}$mice (42). This
C. 糖鎖遺伝子 (糖転移酵素遺伝子) ノックアウトマウスを利 用した糖鎖機能解析

現在では、約 186 種類を超えるヒ卜糖転移酵素遺伝子の 報告がなされている。遺伝子が明らかになるとともに、糖 鎖遺伝子が原因となって生じるヒ卜疾患も明らかとなって きた。例えば、先天性糖鎖合成異常症 (Congenital Disorders of Glycosylation; CDG) やある種の先天性筋ジストロフィー (Muscle-Eye-Brain 病、Walker-Warburg 病) など、糖転移酵 素遺伝子が原因となる疾患が数多く存在することが次第に分 かってきている (35-39)。

このように、糖鎖は非常に重要な生物機能を有している と考えられる。従来、糖鎖の機能解析は非常に困難であったが、 糖鎖遺伝子がクローニング、解析されることによって、遺伝 子ノックアウトマウスが作製できるようになり、糖鎖あるい は糖タンパク質、糖脂質の細胞における生理機能が明らかに されつつある。

ポリラクトサミンは様々な機能を担った重要な糖鎖構造 であると考えられているが、その一方で、実際にポリラクト サミンがどのような分子の上にどの程度伸張しているのか、 あるいはその具体的な機能は何か、といった詳細については 未だよく分かっていない。そこで、幾つかの研究グループに より、ポリラクトサミンを欠損させたマウスを解析すること でそれを明らかにしょうと試みられている。例えば、ポリラ クトサミンを欠損させたマウスの 1 系統（B B g n t 2 遺伝子ノッ クアウトマウス) ではシナプス形成不全による嗅感覚の欠損 が観察されるので、嗅球神経の神経支配域のシナプス形成に 必要であると考えられている(40)。我々もポリラクトサミン 糖鎖の生物学的な機能を明らかにしていきたいと考え、ポリ ラクトサミン鎖合成に関与する 2 系統のノックアウトマウス を作製し、まずは免疫系の表現型から解析を行うこととした $(41,42)$ 。

\section{B3gnt2 遺伝子ノックアウトマウスにおける免疫機能不全 (表現型) の解析}

我々は始めに、主要なポリラクトサミン合成酵素である と考えられる、 $\beta 1,3-N$ - アセチルグルコサミン転移酵素 2(B3gnt2) 遺伝子のノックアウトマウス (B3gnt2 - マウウス)の 解析を行った (42)。本B Bgnt2 - マウスでは、野生型 (WT) マ ウスに比較して、(長鎖) ポリラクトサミン鎖の量が大きく減 少していた。本研究ではポリラクトサミン構造を検出するた めに、Lycopersicon esculentum (トマト) レクチン (LEL)を 使用した。この LEL は、ラクトサミン構造が 3 回以上繰り返 したポリラクトサミン構造に強く結合するため、ポリラクト サミン鎖に対するプローブとして使用出来る (43、44)。LEL を 使用したフローサイトメトリー解析やウェスタンブロット解 析、代謝標識による糖鎖解析の結果、B Bgnt 2 \%ママウスの組織 
suggested that $\beta 3 \mathrm{GnT} 2$ has major polylactosamine synthase activity for synthesizing polylactosamine chains on $N$-glycan.

Next, we predicted that the B3gnt $2^{-/-}$cells would lack polylactosamine chains on $N$-glycans on their cell-surface glycoproteins. We tried to identify cell-surface proteins carrying polylactosamine by using an antibody-overlay lectin microarray analysis (45) (Fig. 2). We screened molecules such as major CD antigens (CD4, CD8 $\alpha$, CD19, CD28, and others) from WT lymphocytes and B3gnt $2^{-/-}$lymphocytes by lectin microarray analysis. In the case of a polylactosamine-carrier molecule, the immunoprecipitated protein exhibits binding (positive) signals on LEL, STL (Solanum Tuberosum, Potato Lectin), and/or others. We screened polylactosamine-carrier molecules by index for a decrease or loss of lectin signals on target molecules derived from the B3gnt $2^{-/}$mouse. As a result, the LEL signal was decreased on immunoprecipitated CD28 in B3gnt2-/ T cells as compared with WT T cells (Fig. 3). Similarly, the LEL signal was decreased on immunoprecipitated CD19 in B3gnt2-/- B cells (Fig. 4).
では、糖タンパク質の $N$-glycan 上の長鎖ポリラクトサミン構 造が有意に減少していることが明らかとなった (42)。以上よ り、in vivoにおいては本酵素が糖タンパク質 $N$-glycan 上のポ リラクトサミン合成の主たる役割を担っていることが明らか となった。

次に、我々はB Bgnt2 - 免疫細胞では、その細胞表面上の 糖タンパク質の $N$-glycan 上でポリラクトサミン鎖が欠損して いると予測した。そこで、抗体オーバーレイ・レクチンアレ イ法 (45) による、ポリラクトサミンが付加した細胞表面分子 の同定を試みた (図 2)。この方法では、主要な CD 抗原 $(\mathrm{CD} 4$ 、 CD8a、CD19、CD28、その他) などを対象に、抗体を使用し て免疫沈降法で分子を濃縮してレクチンアレイに供した (42)。 ポリラクトサミンを含有する分子の場合、レクチンアレイ上 の LEL あるいはSTL (Solanum Tuberosum, Potato Lectin)な どのレクチンへの結合のシグナルが検出される。このシグナ ルがB Bgnt2 - マウス由来の分子では減少あるいは消失すると いうことを指標にスクリーニングした。その結果、CD28 ( T 細胞由来)（図 3）あるいは CD19（B 細胞由来）（図 4）分子 などを同定した。B3gnt2\%マウスにおいては、それらの分子

\section{Glycan Profiling using Antibody-Overlay Lectin Microarray}

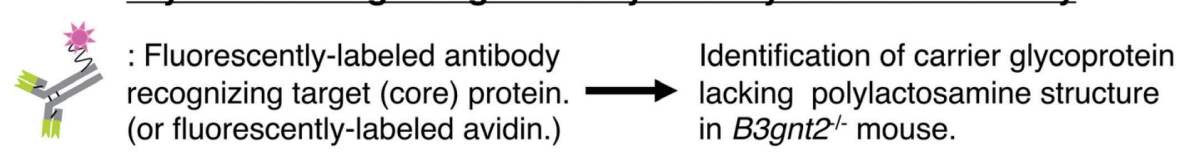

\section{WT proteins}
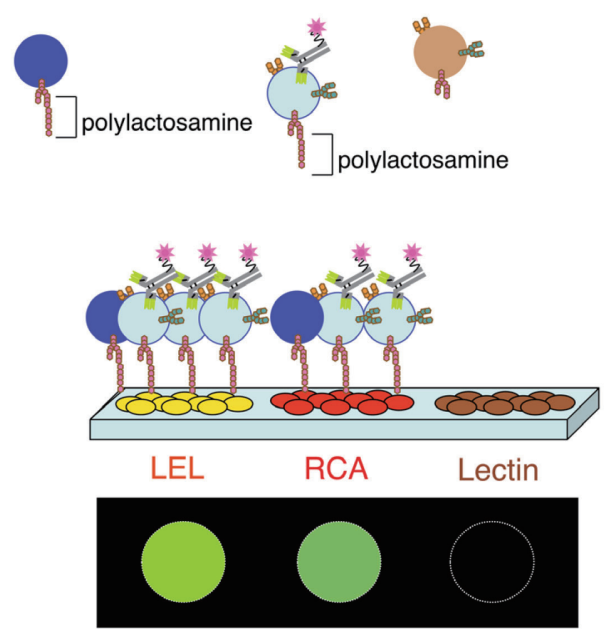

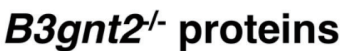

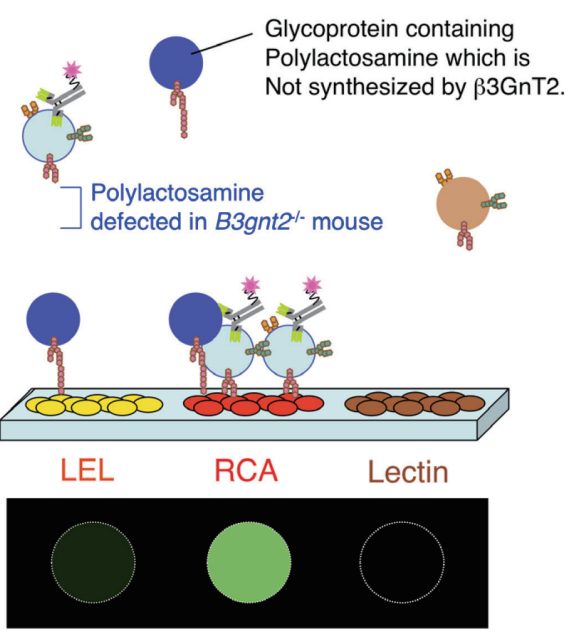

Fig. 2. Schema of analysis of glycan profile on cell-surface proteins by antibody-overlay lectin microarray. Cell-surface immunoprecipitated proteins were analyzed using lectin microarrays (45). Surface proteins of isolated T or B cells were labeled with biotin, and target proteins were immunoprecipitated with antibody. To visualize native glycans on cell-surface proteins, interactions of the target protein with lectins immobilized on glass slides were analyzed. Briefly, immunoprecipitated protein was released and then applied to a microarray containing 43 kinds of lectins. A fluorescently-labeled antibody that recognizes target (core) proteins or fluorescently-labeled avidin, which binds to immunoprecipitates of biotinylated target proteins, was used as the probe for lectin microarray analysis (42). The glass slide was scanned by an evanescent-field fluorescence scanner, SC-Profiler (GP Biosciences Ltd., Yokohama, Japan). Polylactosamine was identified by LEL (tomato lectin) signals. The LEL-binding epitope consists of more than three repeated lactosamine units. Glycoproteins derived from WT mice give LEL signals for polylactosamine-carrying proteins. By contrast, there were no LEL signals on glycoproteins from $B 3 g n t 2^{-/}$mice, indicating a loss of polylactosamine chains. WT, wild-type; $B 3 g n t 2^{-/}$, homozygous null. 
We confirmed the loss of polylactosamine chains on these molecules by an alteration in molecular size using Western blot analysis (Fig. 3A, 4A).

We also examined whether immunological abnormalities were present in T cells and B cells of B3gnt $2^{-1-}$ mice. CD28 and CD19 molecules are known co-stimulatory receptors in T cells and $\mathrm{B}$ cells, respectively. CD28 and CD19 both regulate major immune system signaling, such as $\mathrm{T}$ cell receptor (TCR) and $\mathrm{B}$ cell receptor (BCR) signaling. Thus, we looked for abnormalities of signal transduction involved in TCR and BCR signaling. As a result, B3gnt $2^{-/-}$ $\mathrm{T}$ cells were more sensitive to the induction of intracellular $\mathrm{Ca}^{2+}$ flux on stimulation with anti-CD3e/CD28 antibodies and exhibited upregulation of phosphorylation signals. As it is known that cell proliferation occurs after TCR stimulation,
上に結合しているポリラクトサミンが欠損していることをウ エスタンブロット解析での分子量の変化より確認した (図 3A、 $4 \mathrm{~A})$ 。

次に、 $\mathrm{T}$ 細胞や $\mathrm{B}$ 細胞の免疫機能異常が認められるのか について調査した。これら CD28 分子ゃCD19 分子は、T細 胞レセプター (TCR) 刺激あるいは B 細胞レセプター (BCR) 刺 激などのシグナルに関与する (制御する) 共刺激受容体分子 (co-stimulatory receptor) であることが知られている。そこで、 TCR や BCR 関連のシグナル伝達に異常が認められるかどう かを確認した。抗 CD $3 \varepsilon$ および抗 CD28 抗体で T 細胞を刺激 したところ、B Bgnt2 $2^{\%} \mathrm{~T}$ 細胞では細胞内カルシウムシグナル の充進 (図 3B) やリン酸化シグナルの充進 (図 3C) が認められ た。それらの各種シグナルの立進の結果として、細胞増殖応 答が起こることが知られているが、B $3 g n t 2 \%$ 細胞では野生 型 $\mathrm{T}$ 細胞と比較して、細胞増殖応答が大きく克進されている
A CD28 molecule ( $\mathrm{T}$ cell)

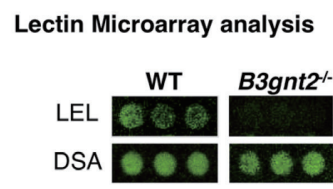

Western Blotting analysis
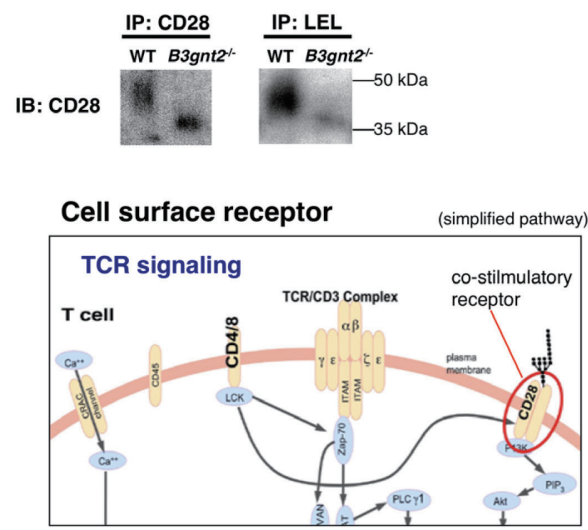

B Intracellular Phosphorylation Signals

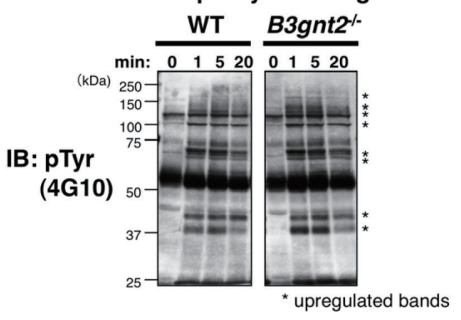

C Calcium influx analysis

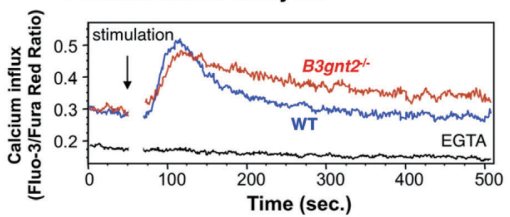

D TCR stimulation (T cell proliferation)

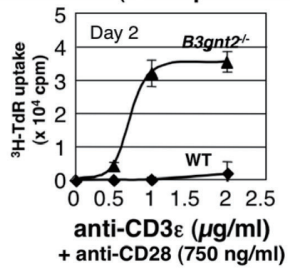

Fig. 3. B3gnt2 ${ }^{-/-} \mathbf{T}$ cells are hypersensitive to stimulation via TCR/CD28. (A) Polylactosamine on $N$-glycans of CD28 molecules in B3gnt ${ }^{--} \mathrm{T}$ cells is diminished. The immunoprecipitates of WT CD28 molecules were found to have LEL-reactive polylactosamine chains on their $N$-glycans. However, the immunoprecipitates of B3gnt $2^{-/} \mathrm{CD} 28$ molecules exhibited a loss of LEL signals on the lectin microarray. By contrast, DSA signals showed no difference between WT and $B 3 g n t 2^{-/-}$mice. DSA recognizes the $N$-glycan core structure. For Western Blotting, immunoprecipitation was carried out with anti-CD28 monoclonal antibody (left), or LEL-agarose (right). The mobility of immunoprecipitated CD28 and on SDSPAGE differed between WT and B3gnt $2^{-/}$cells. In addition, these molecules were only marginally detected in LEL-agarose immunoprecipitates from $B 3 g n t 2^{-/}$mice. These results indicate that the $\mathrm{N}$-glycan core shows no alteration, and only the amount of polylactosamine chains on the $N$-glycans is decreased in B3gnt $2^{-1-}$ mice. CD28 exists on the T cell surface and transfers secondary signals of TCR-related signals as co-stimulatory molecules (bottom). (B) Analysis of phosphorylation status. Resting $\mathrm{T}$ cells from the spleen were stimulated by cross-linking anti-CD3\&/CD28 antibody for the indicated time. $B 3 g n t 2^{-/-} \mathrm{T}$ cells exhibited significantly upregulated phosphorylation signals. (C) Intracellular calcium assays were used to compare the response of WT and B3gnt $2^{--} \mathrm{T}$ cells to anti-CD3/anti-CD28 stimulation. After stimulation, calcium levels returned more slowly to the basal level in $B 3$ gnt $2^{-/}$than in WT splenic T cells. (D) Investigation of CD3/CD28-induced T cell proliferation. $\left[{ }^{3} \mathrm{H}\right]$-thymidine uptake was measurable at day 2 in an anti-CD3 $\varepsilon$ antibody and anti-CD28 antibody dosedependent manner in B3gnt $2^{-/}$splenic T cells but not in WT T cells, which proliferated later.WT, wild-type; $B 3 g n t 2^{-/}$, homozygous null; IP, immunoprecipitation; IB, immuno-blot. 
B3gnt $2^{-1-} \mathrm{T}$ cells proliferated more strongly than WT T cells. On the other hand, B3gnt $2^{-/} \mathrm{B}$ cells also exhibited upregulation of phosphorylation signals on stimulation with anti-BCR antibody (Fig. 4B). B3gnt2 ${ }^{-/}$B cells also showed hyperproliferation on BCR stimulation (Fig. 4C). These studies show that lack of polylactosamine chains on $N$-glycans results in enhanced initiation of immune responses by $\mathrm{T}$ cells and $\mathrm{B}$ cells.

\section{E. Analysis of Immunological Disorder (Phenotype) in the B3gnt5-Deficient $\left(\right.$ B3gnt5 $\left.^{-/}\right)$Mouse}

Second, we generated and analyzed $B 3 g n t 5$ deficient $\left(B 3 g n t 5^{-/}\right)$mice lacking $\beta 3 \mathrm{GnT} 5$, which is a lactotriaosylceramide $\left(\mathrm{Lc}_{3} \mathrm{Cer}\right)$ synthase synthesizing polylactosamine chains on glycolipids (41). B3gnt $5^{-/}$mice showed loss of the precursor structure for lacto/neolactoseries glycolipids (containing polylactosamine chains). We
ことを明らかにした(図 3D)。

一方、B 細胞を抗 $\mathrm{BCR}$ 抗体で B 細胞を刺激したとこ ろ、B Bgnt2 - B 細胞にリン酸化シグナルの艺進が認められた (図 4B)。B 細胞でも、BCR 刺激に伴う細胞増殖応答が大き く元進されていることを明らかにした(図 4C)。本研究では、 $N$-glycan 上のポリラクトサミン鎖の減少が種々の免疫の刺激 に対する免疫応答性を大きく艺進させていることを明らかに した。

E. B3gnt5 遺伝子ノックアウトマウスにおける免疫機能不全 ( 表現型) の解析

次に、糖脂質上のポリラクトサミンの合成に関与す る、 $\beta 1,3-N$ - アセチルグルコサミン転移酵素 5 (B3gnt5) ノッ クアウトマウス $(B 3 g n t 5$ - マウス)を用いて免疫系の表 現型を中心に解析を行った (41)。本B Bgnt5 - マウスでは lactotriaosylceramide $\left(\mathrm{Lc}_{3} \mathrm{Cer}\right)$ を欠失することで、ラクト・ネ オラクト系列糖脂質 (ポリラクトサミン構造が伸張する ) が欠
A

CD19 molecule (B cell)

Lectin Microarray analysis

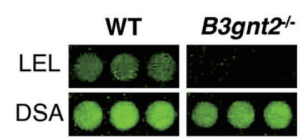

Western Blotting analysis
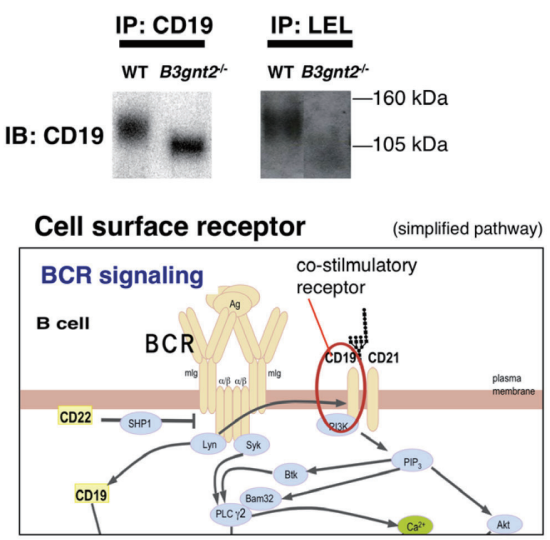

B

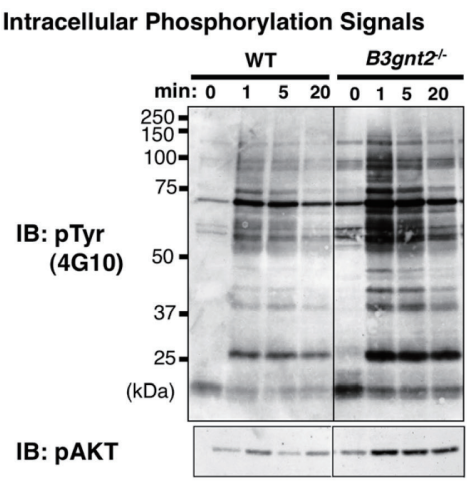

C BCR stimulation (B cell proliferation)

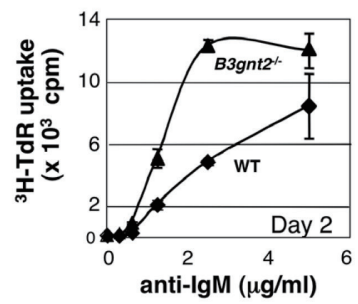

Fig. 4. B3gnt $2^{-/-}$B cells are hypersensitive to stimulation via BCR/CD19. (A) Polylactosamine on $N$-glycans of CD19 molecules in B3gnt2 ${ }^{-/-}$lymphocytes is diminished. The immunoprecipitates of WT CD19 molecules were found to have LEL-reactive polylactosamine chains on their $N$-glycans. However, the immunoprecipitates of B3gnt $2^{-/}$CD19 molecules exhibited a loss of LEL signals on the lectin microarray. By contrast, DSA signals showed no difference between WT and $B 3 g n t 2^{-/}$mice. DSA recognizes the $\mathrm{N}$-glycan core structure. For Western Blotting, immunoprecipitation was carried out with anti-CD19 monoclonal antibody (left), or LEL-agarose (right). The mobility of immunoprecipitated CD19 and on SDSPAGE differed between WT and B3gnt $2^{-/}$cells. In addition, these molecules were only marginally detected in LEL-agarose immunoprecipitates from $B 3 g n t 2^{-/-}$mice. These results indicate that the $\mathrm{N}$-glycan core shows no alteration, and only the amount of polylactosamine chains on the $N$-glycans of CD28 is decreased in B3gnt $2^{-/-}$mice. CD19 exists on the B cell surface and transfers secondary signals of BCR-related signals as co-stimulatory molecules (bottom). (B) Analysis of phosphorylation status. Resting B cells from the spleen were stimulated by cross-linking anti-BCR antibody for the indicated time. The same volume of lysates was added to each lane. Phosphorylated proteins were analyzed by immunoblots using anti-phospho-tyrosine (Tyr) monoclonal antibody (clone 4G10). B3gnt2 ${ }^{-/-} \mathrm{B}$ cells exhibited significantly upregulated phosphorylation signals. (C) Effect of polylactosamine deficiency on B cell proliferation. Resting B cells were stimulated with anti-IgM and proliferation was assessed after 2 days. A greater proliferation of $B 3 g n t 2^{-/}$splenic cells than of WT splenic B cells was observed with low concentrations of anti-IgM.WT, wild-type; $B 3 g n t 2^{-/}$, homozygous null; IP, immunoprecipitation; IB, immuno-blot. 
analyzed the glycan structure of glycolipids derived from WT and $B 3 g_{n t 5} 5^{-1}$ mice. On biochemical analyses, lacto/neolactoseries glycolipids were confirmed to be absent and no $\mathrm{Lc}_{3} \mathrm{Cer}$ synthase activity was detected in the tissues of $B 3 g n t 5^{-/-}$mice. In addition, mass spectrometric analysis revealed that lacto and neolacto-glycolipids had disappeared in $B 3 g n t 5^{-/} \mathrm{B}$ cells. These results demonstrate that $\beta 3 \mathrm{GnT} 5$ is the sole enzyme synthesizing $\mathrm{Lc}_{3} \mathrm{Cer}$ in vivo.

Next, we performed functional analysis (phenotype screening) using immune cells, especially B cells. We screened for phenotypes related to glycolipid-enriched microdomains (GEMs, also known as glycolipid rafts, or detergent-resistant membrane structures, DRMs) (46-49), because the product of $\beta 3 \mathrm{GnT} 5$ is $\mathrm{Lc}_{3} \mathrm{Cer}$ glycolipid and this glycolipid exists in microstructures such as GEMs on the cell surface. GEMs are composed of cholesterol, sphingolipid, glycolipid, and others. In general, GEMs are essential cellular structures for localizing signal transduction $(50,51)$, and lacto/ neolacto-series glycolipids containing polylactosamine are thought to be localized in GEMs. Thus, we thought that these glycolipids might have a function in GEMs.

One glycolipids, GM1 ganglioside, is used as a GEM marker. Thus, we analyzed GEM structure in B cells by GM1 staining with fluorescently labeled cholera toxin B subunit. GM1 staining was significantly upregulated in $B 3 g n t 5^{-/} \mathrm{B}$ cells as compared with WT B cells by fluorescence microscopy analysis (Fig. 5A). The GEM-stained puncta on the surface of $B 3 g n t 5^{-/}$resting B cells were brighter and larger than those of WT cells. These results suggest that structural alteration of GEMs occurs in B3gnt5 $5^{-1} \mathrm{~B}$ cells. At present, however, the detailed phenomenon and molecular mechanism are unknown.

The major biological function of $\mathrm{B}$ cells is immune response and signal transduction involving the BCR and BCR-related molecules. Many studies reported that the BCR and BCR-related molecules such as CD19 transmit their signals in GEMs on the cell surface. In the case of B cells, BCR and CD19 proteins are found outside of GEMs without stimulation. However, these molecules flow to the inside of GEMs after antigen stimulation. This leads to an accumulation of BCR, CD19 and signal transduction molecules in the GEMs. The intracellular signal is then delivered to each cell.

We therefore examined whether BCR signaling-related proteins, such as the BCR, CD19 and the signaling molecule Lyn, had moved into or out of the GEM fraction. These molecules were enriched in the GEM fraction of B3gnt5 $5^{-1-} \mathrm{B}$ cells (Fig. 5B). Moreover, B3gnt $5^{-/-} \mathrm{B}$ cells were more sensitive to the induction of intracellular phosphorylation signals on BCR stimulation (Fig. 6A), and B3gnt $5^{-/} \mathrm{B}$ cells proliferated more vigorously than WT B cells (Fig. 6B). Moreover, T cellindependent antibody production was slightly upregulated at an early stage of the response in B3gnt5-- mice as compared
損する。まず、我々は糖脂質糖鎖構造の解析を行った。生化 学的な解析を行った結果、B $3 g n t 5$ マ文スではラクト・ネオ ラクト系列糖脂質が消失しており、また、B $3 g n t 5 \%$ マウス組 織抽出物中の $\mathrm{Lc}_{3} \mathrm{Cer}$ 合成酵素の活性も検出されなかった。質 量分析器による糖鎖構造解析でも、B $3 g n t 5$ - B 細胞ではラク 卜・ネオラクト系列糖脂質糖鎖が消失していることが明らか となった。これらの結果は、この酵素が生体内で糖脂質上の ポリラクトサミン糖鎖の合成を担っている唯一の酵素である ということを示している。

次に、免疫細胞、特に B 細胞を対象に機能解析 ( 表現型 スクリーニング) を行った。生成物が $\mathrm{Lc}_{3} \mathrm{Cer}$ 糖脂質であり、 これら糖脂質が糖脂質マイクロドメイン (glycosphingolipidsenriched microdomain: GEM、あるいは糖脂質ラフト: glycolipid raft detergent-resistant membrane structures: DRMs とも言われる) (46-49)のような細胞表面の微細構造内 部に局在することから、我々は、GEM(ラフト)構造と関連す る表現型をスクリーニング解析した。GEM 構造はコレステロ ールやスフィンゴ脂質、糖脂質その他で構成されており、シ グナル伝達の場として必須な細胞構造である (50、51)。ポリラ クトサミン鎖を含有する、ラクト・ネオラクト系列糖脂質も GEM 構造に局在していると考えられる。その為、我々はこれ らの糖脂質が GEM において何らかの機能を果たしているので はないかと考えた。

糖脂質の一つである GM1 ガングリオシドが GEM 構造の マーカーとして用いられていることは一般的である。そこで、 我々はB 細胞の GEM 構造を蛍光標識されたコレラ毒素で染 色して解析を行った。B3gnt5 B B 細胞では、コレラ毒素によ る GM1 染色性が野生型 B 細胞に比較して大きく克進していた (図 5A)。マウスの休止 B 細胞では、野生型に比較して、パッ チ状の GEM 染色像がより強く且つ大きく観察された。このこ とから、糖脂質ポリラクトサミンの欠失により糖脂質マイク ロドメイン構造に何らかの変化が起きていることが示唆され た。しかしながら、現時点では詳細な分子メカニズムなどを 含め不明である。

$\mathrm{B}$ 細胞の主要な機能は、 $\mathrm{BCR}$ 分子を中心とした免疫反応 であることはよく知られている。それら BCR 分子や関連分子 であるCD19 分子などは、そのシグナルを細胞膜上の GEM 構 造に抒いて伝達していることが多数報告されている。例えば B 細胞では、細胞への刺激が無い状態では、BCR P CD19夕 ンパク質分子は GEM 構造の外側にいるが、抗原による刺激が 加わると、これらの分子は GEM 構造内に流入する。そして、 $\mathrm{GEM}$ 構造内への $\mathrm{BCR}$ 分子、 CD19 分子、シグナル伝達分子な どの集積により、細胞内へとシグナルが伝えられていく。

そこで我々は、BCR P CD19 抢よびシグナル伝達分子で ある Lyn などの BCR シグナル関連分子群が GEM 構造内外 へどのように移動しているのかを解析した。その結果、GEM 構造へのこれらの分子などの移入 (挙動)に差が見られる (B3gnt5 - マウスでは GEM への局在が充進する) ことが明らか となった(図 5B)。また、B $3 g n t 5$ - B 細胞では BCR 刺激によ るリン酸化シグナルの光進が認められた(図 6A)。B3gnt5 マ 
with WT mice (Fig. 6C). These results suggested that B3gnt $5^{-/-}$ $\mathrm{B}$ cells tend to be more easily activated by BCR stimulation as compared with WT B cells.

Together, these results suggest that lacto/neolactoseries glycolipids containing polylactosamine play an important role in controlling the clustering and stabilization of GEMs as a platform for signal transduction, and thereby regulate the movement of specific proteins, such as BCRrelated molecules, to GEMs.

In addition, some research groups have generated and analyzed different strains of B3gnt5-deficient mice (41, 52-54). It has been reported that disruption of the B3gnt5 gene leads to abnormalities in reproduction function such as preimplantation lethality, sex behavior, and immune response (52-54). There are many differences among the B3gnt5deficient mouse strains. At present, however, it is unclear why these differences were observed.

A

CT-B staining levels for the GEM puncta of B3gnt5 $\%$ resting cells were almost as high as for stimulated WT B cells

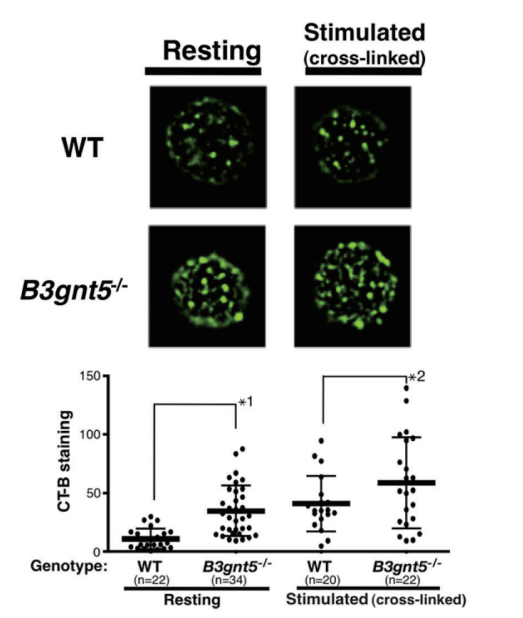

ウス B 細胞では、野生型マウスに比較して細胞増殖応答の立 進が認められることが分かった(図 6B)。さらに、T 細胞非依 存性の抗体産生能を解析した結果、B Bgnt5- マウスでは野生 型マウスと比較して初期段階での応答が充進していた。これ らの結果から、BCR 刺激において、B B gnt 5 \% B 細胞は野生型 $\mathrm{B}$ 細胞よりも活性化し易いことが示唆された。

以上より、ポリラクトサミン糖鎖を含有するラクト・ネオ ラクト系列糖脂質は、シグナル伝達の場としての GEM 構造の 会合や安定化の制御において重要な役割を担っており、BCR シグナル関連の特定の分子の GEM 構造への移動の制御をして いるのではないかと考えられる。

ちなみに、B3gnt5 遺伝子のノックアウトマウスについて は、幾つかの研究グループによっても、複数のマウス系統が 作製され、解析されている $(41 、 52-54)$ 。その結果、糖脂質上の ポリラクトサミンが受精卵の着床などの生殖機能異常や性行 動、免疫異常などが報告されている (52-54)。このように、樹 立された各々のマウス系統で表現型の違いが見出されている のだが、その系統ごとの違いが何故生じるのかについては現 時点ではよく分かっていない。

B

Distribution analysis of GEM proteins.

Co-stimulated with anti-BCR/CD19 Abs

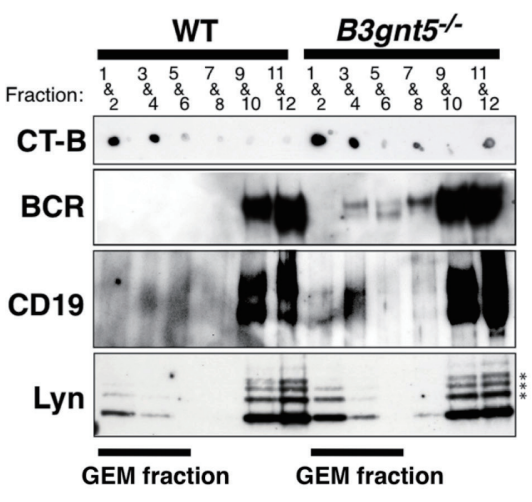

Fig. 5. Upregulation of cholera toxin B-subunit (CT-B) staining as a glycolipid-enriched microdomain (glycolipid raft) marker and distribution of GEM proteins in B3gnt5 ${ }^{--}$B cells. (A) Fluorescence microscopy of GEMs on the cell surface. Fluorescence microscopy showed a CT-B-induced punctate pattern indicating GEM structures on the B cell surface (upper panel). Resting or stimulated isolated B cells were stained with FITCconjugated CT-B. The results shown are representative of several independent experiments revealing markedly stronger staining of $B 3 g n t 5^{-/-}$than of WT B cells. The fluorescence intensity of positive signals for each CT-B-stained punctate region was analyzed by a BZ-Analyzer (KEYENCE) (lower panel). The total value of the positive signals on each cell surface was measured. Statistical analysis of the difference between WT and B3gnt $5^{-/}$B cells, with or without stimulation, was performed using one-way ANOVA and Tukey testing by GraphPad PRISM4 software. Data are given as each cell and means (bold line) and standard deviation. $\mathrm{P}$ values are $* 1: \mathrm{P}<0.01, * 2: \mathrm{P}<0.01$. (B) Distribution of BCR, CD19, and Lyn in GEMs separated into fractions by sucrose density gradient centrifugation. B cells stimulated with anti-BCR and anti-CD19 antibodies were lysed with 1\% Triton X-100 solubilization buffer. After sucrose gradient centrifugation, fractions were collected from the top of the gradient. Next, every second fraction was combined starting from the top fraction. GM1, as a GEM marker, was detected using HRP-conjugated CT-B, as shown in the upper panel. After fractionation, immunoprecipitation of the BCR and CD19 was performed using anti-BCR and anti-CD19 antibody, respectively. BCR (sIgM) and CD19 proteins in B3gnt $5^{-1 /}$ B cells were upregulated in the GEM fraction (fractions 1-4). Lyn protein was also upregulated in the GEM fraction of $B 3 g n t 5^{-/-} \mathrm{B}$ cells. The results shown are representative of several independent experiments. *: non-specific bands. 


\section{F. Regulation of the Immune Response by Polylactosamine}

Our work has strongly indicated that the long polylactosamine chains on $\mathrm{N}$-glycans are synthesized by $\beta 3 \mathrm{GnT} 2$ (42). In addition, lacto and neolacto-series glycolipids are synthesized by $\beta 3 \mathrm{GnT5}$ (41). These studies suggested that polylactosamine deficiency either on receptor glycoproteins on the cell surface or on glycolipids leads to hyperresponsiveness of lymphocytes to external stimuli.

Our studies also suggested that polylactosamine chains on glycoproteins ( $N$-glycans) play important roles in controlling the assembly and stabilization of receptor complexes via an inhibitory mass effect of polylactosamine on molecular interactions. In addition, our study suggested that lacto/neolacto-series glycolipids play an important role in the formation and function of GEM structures. From these studies, we think that the polylactosamine chain is one of the important factors that determines the thresholds for immune responses at a cellular level.

On the cell surface, there seems to be a microstructure known as a lattice structure ((poly)lactosamine-mediated lattice) $(55,56)$ (Fig. 7A, left side of figure, lattice theory).
F. ポリラクトサミン糖鎖による免疫反応の制御

我々はこれらのノックアウトマウスでの機能解析を通じ て、 $\beta 3 \mathrm{GnT}$ 2 が生体内では主として $N$-glycan 上の長鎖ポリラ クトサミン鎖の合成に関与していること (42)、 $\beta 3 \mathrm{GnT}$ T がラク

ト・ネオラクト系列糖脂質糖鎖上のポリラクトサミン鎖の合 成に関与していることを明らかにした (41)。そしてこれらの研 究から、免疫細胞表面の糖タンパク質受容体や糖脂質に結合 しているポリラクトサミン鎖の消失は、外部刺激に対するリ ンパ球の過剩な活性化を引き起こすことが示唆された。

我々の研究より、糖タンパク質 ( $N$-glycan) 上のポリラクト サミンが受容体タンパク質の会合や(受容体タンパク質複合体 の)安定化に重要であることが示唆された。これらは分子間相 互作用に扔いて、受容体タンパク質に結合するポリラクトサ ミン鎖が、その物理的質量により、受容体タンパク質の会合 を抑止する (邪魔をする) ことによるものと思われる。また、 ラクト・ネオラクト系列糖脂質が受容体シグナルの伝達の場 である GEM 構造の形成や機能に重要な機能を果たしているこ とが示唆された。これらの研究から、我々はポリラクトサミ ン糖鎖が細胞レベルでの免疫応答の閾值を決定する重要な因 子の一つなのではないかと考えている。
A Phosphorylation signals with $B C R / C D 19$ cross linking were upregulated in $B 3 g n t 5^{-} \mathrm{B}$ cells

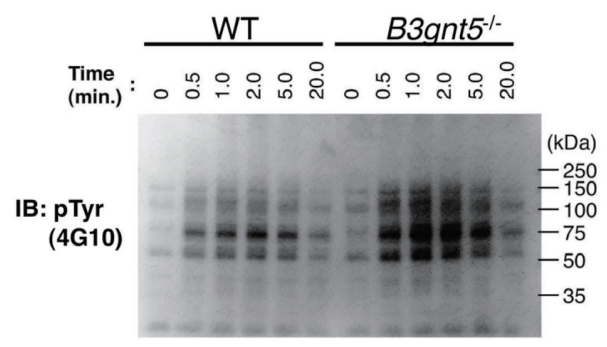

B Resting B cells from B3gnt $5^{-/}$mice show enhanced responses to BCR-mediated stimulation.

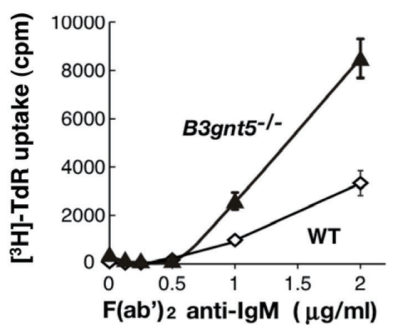

C Antibody production to T cell-independent type II antigen

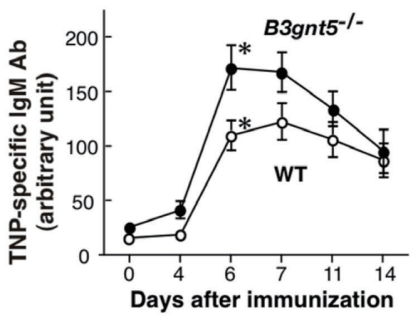

Fig. 6. Phosphorylation signals with BCR/CD19 cross-linking are upregulated in $B 3 g n t 5^{-/-} \mathrm{B}$ cells. (A) Analysis of phosphorylation status. Resting B cells from the spleen were stimulated by cross-linking anti-BCR antibody for the indicated time. $B 3 g n t 5^{-1} \mathrm{~B}$ cells exhibited significantly upregulated phosphorylation signals. (B) Resting B cells from $B 3 g n t 5^{-1-}$ mice show enhanced responses to BCR-mediated stimulation. Resting $\mathrm{B}$ cells were cultured with the indicated dose of $\mathrm{F}\left(\mathrm{ab} \mathrm{b}^{\prime}\right)_{2}$ anti-IgM. Proliferative responses were detected by $\left[{ }^{3} \mathrm{H}\right]-$ TdR incorporation. B3gnt5 $5^{-/ 2}$ B cells showed hyper-proliferation by BCR stimulation as compared with WT B cells. (C) Immune response to T cell-independent type II antigen (as antibody production). We examined the in vivo response to the T-independent type II antigen as B cell function. Mice were immunized intraperitoneally with Trinitrophenol (TNP)-Ficoll as immunogen at day 0 . The levels of TNP-specific IgM antibody in sera were determined by ELISA. The levels of TNP-specific IgM production were slightly upregulated at an early stage of the response in $B 3 g n t 5^{-/}$mice as compared with WT mice. The levels of IgM in serum are presented as means (symbols) \pm S.E.. P values are *: P<0.05. Open circles: WT mice; closed circles: $B 3 g n t 5^{-/ 2}$ mice. 
This lattice structure is formed by cross-linking between glycoproteins (containing multivalent glycan) and endogenous lectins (having multivalent binding sites), such as galectin (57). The lattice structures regulate signal transduction and the threshold of cellular responses by controlling movement and turnover (half-life) of receptor glycoproteins (58-61). In addition, it is thought that lattice structures modulate cellular interactions.

In WT mice, BCR proteins are associated after stimulation and form a GEM structure. This response occurs forcibly under the limitation of molecular actions by the lattice structure. This response results in intracellular signaling to each cell and activation of cells.

In our study on the B3gnt $2^{-/}$mouse, we found
細胞表面には(ポリ) ラクトサミン糖鎖を介した格子構造 (Lattice 構造) という微細な構造 (microstructure) が存在する と考えられている (55、56) (図 7A、図の左側。Lattice 仮説)。 この Lattice 構造は糖タンパク質上の多価の糖鎖が galectinの ような多価の内在性レクチンによって他の分子と架橋されて 形成される構造として考えられている(57)。Lattice 構造は細 胞表面の糖タンパク質分子の動きやターンオーバー (半減期) を制御することで、シグナル伝達や細胞応答の閾值を決めて いると考えられている (58-61)。また、Lattice 構造は細胞間相 互作用なども調節していると考えられている。

野生型マウスでは、抗原などの刺激によって、BCR タン パク質が会合するとともに、GEM 構造が形成される。これは Latticeによる分子の動きが制限された状態で、半ば強制的に

\section{A $\beta 3 G n T 2-d e f i c i e n t ~ m i c e$}

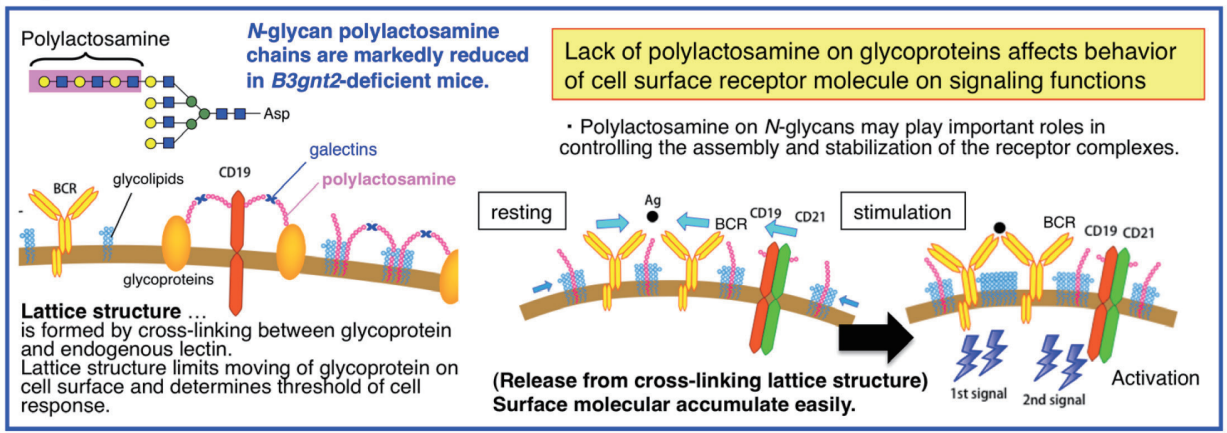

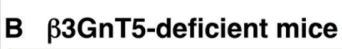

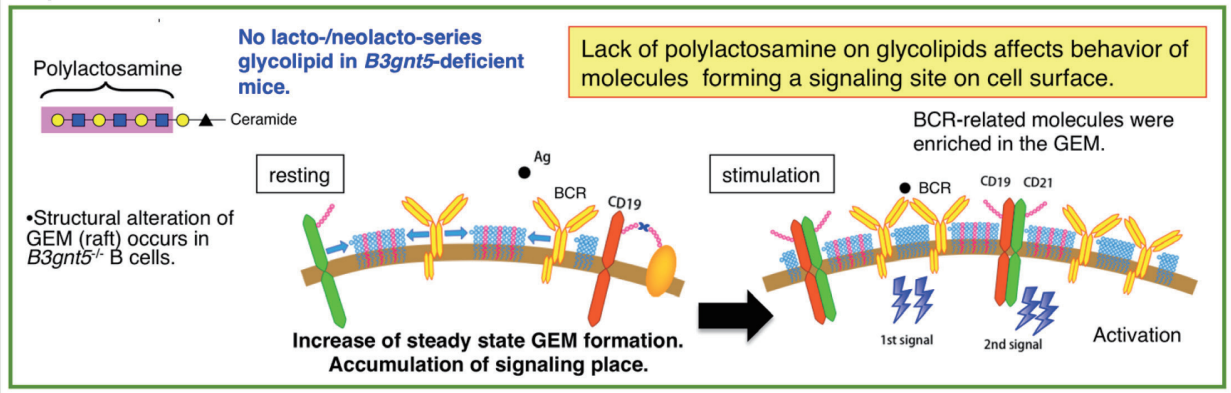

Fig. 7. Biofunction of polylactosamine chains on the cell surface (hypothetical model). Schema of model for movement of receptor glycoproteins and glycolipids (GEM) on the cell surface in B3gnt $2^{-/-}$(A) and B3gnt $5^{-/-}$(B) cells in a resting or activated state. A hypothesis for the abnormalities observed in each knockout cell is suggested. The glyan structures lacking in each knockout mouse are indicated by rectangles. The lattice structure on the cell surface of the WT cell is illustrated on the left of upper panel. In B3gnt $2^{-/}$mice, lack of polylactosamine on glycoproteins induces disappearance of the lattice structure. This makes it easier for receptor glycoproteins to move around on the cell surface. We think that hypoglycosylation of glycoprotein receptors may regulate binding affinity between the receptor and its ligand, or it may regulate association of receptor. In general, GEMs (lipid rafts) are known to be essential for the localization of signal transduction. An important issue in GEM function is aggregation. Under the naïve condition before stimulation, it is known that GEMs are small structures. By clustering GEM-associated proteins, the small individual GEMs cluster into larger, visible and functional units. GEM formation is reversible, and GEMs exist only as transiently stabilized structures. In $B 3 g n t 5^{-/-}$B cells, larger GEM units are made more rapidly as compared with WT B cells. B3gnt $5^{-/-} \mathrm{B}$ cells showed a marked increase in BCR-related molecules, such as BCR, CD19, and the signaling molecule Lyn, in GEMs as compared with WT mice. There are at least two possible molecular mechanisms that could be responsible for the phenomenon observed in $B 3 g n t 5^{-/-}$B cells. First, BCR/CD19 complexes might be transferred efficiently into GEMs, because many more clustered GEMs are formed in B3gnt $5^{-/} \mathrm{B}$ cells than in WT B cells. Second, polylactosamine on glycolipids might control the behavior of glycoprotein entry into or exclusion from GEMs. Dissecting the detailed mechanisms responsible for enhanced GEM formation in $B 3 g n t 5^{-/-} \mathrm{B}$ cells is an attractive subject for future study. In summary, these observations suggest that polylactosamine-deficient cells lead to upregulation of immune responses by abnormal movement of cell-surface proteins and/or formation of the GEM microstructure. 
polylactosamine on the immune co-stimulatory molecules CD28 and CD19, and showed that polylactosamine levels on these molecules were reduced in B3gnt $2^{-/}$immunocytes. In $B 3 g n t 2^{-/}$mice, a reduction of polylactosamine on glycoproteins leads to a lack of lattice structure. We assume that this makes it easier for receptor proteins such as CD28 or CD19, to move around on the cell surface. Consequently, the clustering of receptor proteins in B3gnt $2^{-/}$mice occurs at an earlier stage than in the WT mouse (Fig. 7, right of figure). These observations suggest that B3gnt $2^{-1-}$ lymphocytes tend to be more easily activated by stimulation as compared with WT lymphocytes. We think that hypoglycosylation of glycoprotein receptors may regulate binding affinity between the receptor and its ligand, or it may regulate association of the receptor.

It has been reported that glycolipid are not essential for formation of GEMs (62). However, from our studies on the $B 3 g n t 5^{-/}$mouse, we think that polylactosamine on glycolip ids may play an important role in forming the GEM structure as a signaling platform on the cell surface. Both the association of receptor complexes and the platform formed by clustered GEMs are important for signaling via GEMs. In B3gnt5 $5^{-/}$resting B cells, the small GEMs can easily aggregate into larger units when receptor complexes are formed. Some relations between GEMs and the lattice structure may exist, because it is known that some galectins are localized in the GEM structure. At present, the details of the molecular mechanism are still unclear, but the GEM structure is thought to be stable in $B 3$ gnt $5^{-/} \mathrm{B}$ cells. In any case, larger GEM units are made more rapidly in B3gnt5 $5^{-1-} \mathrm{B}$ cells as compared with WT B cells. Therefore, a larger amount of BCR-related proteins such as the BCR and CD19 molecule, flow into GEMs and activate cells (Fig. 7B). These observations suggest that $B 3 g n t 5^{-1-} \mathrm{B}$ cells tend to be more easily activated after stimulation as compared with WT lymphocytes.

Taken together, these studies have demonstrated that polylactosamine deficiency on glycolipids causes various abnormalities in cellular function through regulation of receptor function and GEM formation. However, further work is needed to clarify both the mechanism of these phenotypes and the hypothesis in detail.

\section{G. Future Perspective}

As a first step to further clarify the function and importance of specific carbohydrate structure, glycogenedeficient mice have been generated and investigated.

In order to elucidate the detailed role of polylactosamine chains on biologically relevant sites, initially we cloned glycosyltransferase genes belonging to the $\beta 1,3-$ glycosyltransferase family, especially $\beta 3 \mathrm{GnTs}$. Subsequently, many studies have shown that these enzymes have different substrate specificities, synthesize characteristic carbohydrate
起こっていると考えられる。その結果、GEM 構造内に抏いて、 細胞内ヘシグナルが伝達され、細胞の活性化を生じる。

一方、B Bgnt2 マ市スを用いた研究から、我々はCD28や $\mathrm{CD} 19$ 分子などの上にポリラクトサミン鎖が結合しているこ とを見出し、これがB B gnt2 - マウウス免疫細胞では減少してい ることを明らかにした。我々は、糖タンパク質上のポリラク トサミン糖鎖の欠損により、Lattice 構造の消失が誘導され、 CD19 を始めとした細胞表面の受容体タンパクが動き易い状態 になっているのではないかと (仮説として) 考えている。その 結果、野生型マウスよりも早く(受容体タンパク質の) クラス タリング(会合)が起こっていると考えている(図 7A、図の 右側)。以上より、B $3 g n t 2$ リンンパ球では野生型と比較して、 細胞の活性化が非常に起こりやすくなっていると示唆される。 我々は、受容体糖タンパク質の糖鎖欠損が受容体タンパク質 とそのリガンドとの間の結合親和性を制御するとともに、受 容体タンパク質の会合をも制御している可能性を考えている。

糖脂質は GEM 構造の形成には必須ではないとの報告がな されている (62) が、B $3 g n t 5$-マウウスの研究から、我々は細胞 表面のシグナル伝達の場としての GEM 構造の形成にポリラ クトサミンが重要な役割を担っていると考えている。受容体 タンパク質の会合と、集積したGEM から成る場 (構造) は、 GEM を介したシグナル伝達に非常に重要である。B $3 g n t 5$-休 止 B 細胞では、元々の小さな GEM 構造が、受容体分子の複 合体の形成によって、より大きな単位に凝集し易いようであ る。GEM 構造内に Galectin が局在するなどしており (66、67)、 GEM 構造と Lattice 構造の間にも何か関連があるのかも知れ ない。現時点では詳細な分子メカニズムは不明だが、B B gnt 5 マウス B 細胞の GEM 構造は安定的になっているのかも知れ ない。いずれにせよ、B $3 g n t 5$-マウスでは、野生型マウスよ りも早く、大きな GEM 構造が出来て扮り、その結果、GEM 内により多くの BCR 分子や CD19 分子が流入していると考え られた(図 7B)。以上より、B3gnt5\%マウスでは細胞の活性化 が起こりやすくなっていると示唆された。

これらの研究により、糖脂質ポリラクトサミンの異常 は、受容体機能や GEM 構造の形成を制御することで様々 な異常を引き起こすことが示された。しかしながら、こ れらの表現型や仮説の詳細について明らかにするために は、さらなる解析を必要として抢り、将来の課題でもある。

\section{G. おわりに}

特定の糖鎖の機能やその重要性をさらに明確にする為の 第一歩として、糖鎖遺伝子ノックアウトマウスの作製と解析 が盛んに行われてきた。生物機能の作用点におけるポリラク トサミン鎖の詳細な役割を明らかにするために、我々はまず、 $\beta 1,3$ - 結合糖転移酵素群に属する糖転移酵素遺伝子、特に $\beta 3 \mathrm{GnT}$ 遺伝子をクローニングした。その後、多くの解析によ って、異なる基質特異性を有しそれぞれ特徵的な糖鎖構造を 合成すること、そして生物学的に異なる機能を担っているこ 
structures, and have biologically different functions. We raise the possibility that the polylactosamine structure on glycoproteins and/or glycolipids might have significant effects on biological function in the immune system.

We believe that gene cloning and analysis of glycogene-deficient mice has laid the basis for further clarification of the importance of functional carbohydrate structures such as polylactosamine.

\section{Acknowledgements}

These studies were supported by the "Glycogene Library: GG", "Śtructural Glycomics: SG", "Medical Glycomics: MG" project in the New Energy and Industrial Technology Development Organization (NEDO) of Japan.
とが明らかになってきた。我々は糖タンパク質や糖脂質上の ポリラクトサミン構造が、免疫システムに扮ける生物学的機 能に抢いて大きな効果を有しているという可能性を示した。

遺伝子の単離と遺伝子ノックアウトマウスの解析により、 ポリラクトサミンのような機能的糖鎖構造の重要性をさらに 明確にする為の基礎が築かれたと考えて良いであろう。

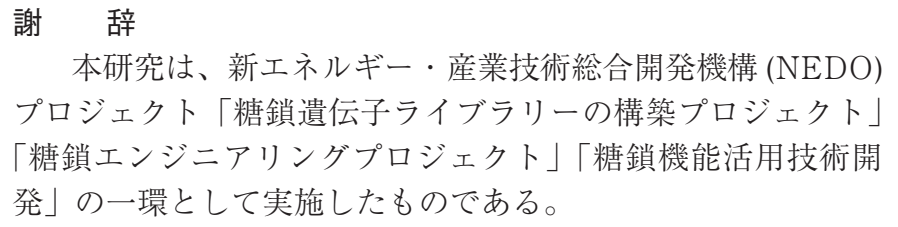

\section{References}

1. Lee, N., Wang, W. C., and Fukuda, M. (1990) J. Biol. Chem. 265, 20476-20487.

2. Renouf, D. V., and Hounsell, E. F. (1993) Int. J. Biol. Macromol. 15, 37-42.

3. Wang, W. C., Lee, N., Aoki, D., Fukuda, M. N., and Fukuda, M. (1991) J. Biol. Chem. 266, 23185-23190.

4. Ujita, M., McAuliffe, J., Schwientek, T., Almeida, R., Hindsgaul, O., Clausen, H., and Fukuda, M. (1998) J. Biol. Chem. 273, 3484334849.

5. Yu, L. C., Twu, Y. C., Chang, C. Y., and Lin, M. (2001) Blood 98, 3840-3845.

6. Inaba, N., Hiruma, T., Togayachi, A., Iwasaki, H., Wang, X. H., Furukawa, Y., Sumi, R., Kudo, T., Fujimura, K., Iwai, T., Gotoh, M., Nakamura, M., and Narimatsu, H. (2003) Blood 101, 2870-2876.

7. Hirabayashi, J., Hashidate, T., Arata, Y., Nishi, N., Nakamura, T., Hirashima, M., Urashima, T., Oka, T., Futai, M., Muller, W. E., Yagi, F., and Kasai, K. (2002) Biochim. Biophys. Acta 1572, 232-254.

8. Arbones, M. L., Ord, D. C., Ley, K., Ratech, H., Maynard-Curry, C., Otten, G., Capon, D. J., and Tedder, T. F. (1994) Immunity 1, 247260.

9. Ellies, L. G., Tsuboi, S., Petryniak, B., Lowe, J. B., Fukuda, M., and Marth, J. D. (1998) Immunity 9, 881-890.

10. Fukuda, M., Hiraoka, N., and Yeh, J. C. (1999) J. Cell Biol. 147, 467-470.

11. Mitoma, J., Bao, X., Petryanik, B., Schaerli, P., Gauguet, J. M., Yu, S. Y., Kawashima, H., Saito, H., Ohtsubo, K., Marth, J. D., Khoo, K. H., von Andrian, U. H., Lowe, J. B., and Fukuda, M. (2007) Nat. Immunol. 8, 409-418.

12. Gilbert, C. W., Zaroukian, M. H., and Esselman, W. J. (1988) J. Immunol. 140, 2821-2828.

13. Saitoh, O., Wang, W. C., Lotan, R., and Fukuda, M. (1992) J. Biol. Chem. 267, 5700-5711.

14. Narimatsu, H., Sinha, S., Brew, K., Okayama, H., and Qasba, P. K. (1986) Proc. Natl. Acad. Sci. U. S. A. 83, $4720-4724$.

15. Amado, K., Almeida, R., Carneiro, F., Leverly, S. B., Holmes, E. H., Nomoto, M., Hollingsworth, M. A., Hassan, H., Schwientek, T., Nielsen, P. A., Bennett, E. P., and Clausen, H. (1998) J. Biol. Chem. 278, 12770-12778.

16. Amado, M., Almeida, R., Schwientek, T., and Clausen, H. (1999) Biochim. Biophys. Acta 1473, 35-53.

17. Hennet, T. (2002) Cell Mol. Life Sci. 59, 1081-1095.

18. Hennet, T., Dinter, A., Kuhnert, P., Mattu, T. S., Rudd, P. M., and Berger, E. G. (1998) J. Biol. Chem. 273, 58-65.

19. Sasaki, K., Kurata-Miura, K., Ujita, M., Angata, K., Nakagawa, S., Sekine, S., Nishi, T., and Fukuda, M. (1997) Proc. Natl. Acad. Sci. U. S. A. 94, 14294-14299.

20. Zhou, D., Dinter, A., Gutierrez Gallego, R., Kamerling, J. P., Vliegenthart, J. F., Berger, E. G., and Hennet, T. (1999) Proc. Natl. Acad. Sci. U. S. A. 96, 406-411.

21. Shiraishi, N., Natsume, A., Togayachi, A., Endo, T., Akashima, T., Yamada, Y., Imai, N., Nakagawa, S., Koizumi, S., Sekine, S., Narimatsu, H., and Sasaki, K. (2001) J. Biol. Chem. 276, 3498-3507.

22. Togayachi, A., Sato, T., Iwai, T., and Narimatsu, H. (2007) Trends Glycosci. Glycotechnol. 19, $29-40$.

23. Bao, X., Kobayashi, M., Hatakeyama, S., Angata, K., Gullberg, D., Nakayama, J., Fukuda, M. N., and Fukuda, M. (2009) Proc. Natl. Acad. Sci.U.S.A. 106, 12109-12114.

24. Togayachi, A., Akashima, T., Ookubo, R., Kudo, T., Nishihara, S., Iwasaki, H., Natsume, A., Mio, H., Inokuchi, J., Irimura, T., Sasaki, K., and Narimatsu, H. (2001) J. Biol. Chem. 276, 22032-22040.

25. Yeh, J. C., Hiraoka, N., Petryniak, B., Nakayama, J., Ellies, L. G., Rabuka, D., Hindsgaul, O., Marth, J. D., Lowe, J. B., and Fukuda, M. (2001) Cell 105, 957-969.

26. Henion, T. R., Zhou, D., Wolfer, D. P., Jungalwala, F. B., and Hennet, T. (2001) J. Biol. Chem. 276, 30261-30269.

27. Chou, D. K., Henion, T. R., and Jungalwala, F. B. (2003) J. Neurochem. 86, 917-931.

28. Chou, D. K., Prasadarao, N., Koul, O., and Jungalwala, F. B. (1991) J. Neurochem. 57, 852-859.

29. Jungalwala, F. B., Chou, D. K., Suzuki, Y., and Maxwell, G. D. (1992) J. Neurochem. 58, 1045-1051.

30. Iwai, T., Inaba, N., Naundorf, A., Zhang, Y., Gotoh, M., Iwasaki, H., Kudo, T., Togayachi, A., Ishizuka, Y., Nakanishi, H., and Narimatsu, H. (2002) J. Biol. Chem. 277, 12802-12809.

31. Kataoka, K., and Huh, N. H. (2002) Biochem. Biophys. Res. Commun. 294, 843-848. 
32. Seko, A., and Yamashita, K. (2004) FEBS Lett. 556, 216-220.

33. Ishida, H., Togayachi, A., Sakai, T., Iwai, T., Hiruma, T., Sato, T., Okubo, R., Inaba, N., Kudo, T., Gotoh, M., Shoda, J., Tanaka, N., and Narimatsu, H. (2005) FEBS Lett. 579, 71-78.

34. Seko, A., and Yamashita, K. (2005) Glycobiology 15, 943-951.

35. Endo, T., and Toda, T. (2003) Biol. Pharm. Bull. 26, 1641-1647.

36. Yoshida, A., Kobayashi, K., Manya, H., Taniguchi, K., Kano, H., Mizuno, M., Inazu, T., Mitsuhashi, H., Takahashi, S., Takeuchi, M., Herrmann, R., Straub, V., Talim, B., Voit, T., Topaloglu, H., Toda, T., and Endo, T. (2001) Dev. Cell 1, 717-724.

37. Schachter, H., Vajsar, J., and Zhang, W. (2004) Glycoconj. J. 20, 291-300.

38. Hennet, T. (2012) Biochim. Biophys. Acta Feb.9(Epub), PMID:22343051.

39. Jaeken, J. (2010) Ann. N. Y. Acad.Sci. 1214, 190-198.

40. Henion, T. R., Raitcheva, D., Grosholz, R., Biellmann, F., Skarnes, W. C., Hennet, T., and Schwarting, G. A. (2005) J. Neurosci. 25, $1894-1903$.

41. Togayachi, A., Kozono, Y., Ikehara, Y., Ito, H., Suzuki, N., Tsunoda, Y., Abe, S., Sato, T., Nakamura, K., Suzuki, M., Goda, H. M., Ito, M., Kudo, T., Takahashi, S., and Narimatsu, H. (2010) Proc. Natl. Acad. Sci. U. S. A. 107, 11900-11905.

42. Togayachi, A., Kozono, Y., Ishida, H., Abe, S., Suzuki, N., Tsunoda, Y., Hagiwara, K., Kuno, A., Ohkura, T., Sato, N., Sato, T., Hirabayashi, J., Ikehara, Y., Tachibana, K., and Narimatsu, H. (2007) Proc. Natl. Acad. Sci. U. S. A. 104, 15829-15834.

43. Leppanen, A., Stowell, S., Blixt, O., and Cummings, R. D. (2005) J. Biol. Chem. 280, 5549-5562.

44. Nachbar, M. S., Oppenheim, J. D., and Thomas, J. O. (1980) J. Biol. Chem. 255, 2056-2061.

45. Kuno, A., Kato, Y., Matsuda, A., Kaneko, M. K., Ito, H., Amano, K., Chiba, Y., Narimatsu, H., and Hirabayashi, J. (2009) Mol. Cell Proteomics 8, 99-108.

46. Hakomori, S. (2004) An. Acad. Bras. Cienc. 76, 553-572.

47. Kasahara, K., and Sanai, Y. (1999) Biophys. Chem. 82, 121-127.

48. Kasahara, K., and Sanai, Y. (2003) Tanpakushitsu Kakusan Koso 48, 1164-1170.

49. Kasahara, K., Sanai, Y., Nakamura, K., and Hashimoto, Y. (2001) Tanpakushitsu Kakusan Koso 46, 812-820.

50. Simons, K., and Ikonen, E. (1997) Nature 387, 569-572.

51. Simons, K., and Toomre, D. (2000) Nat. Rev. Mol. Cell Biol. 1, 31-39.

52. Biellmann, F., Henion, T. R., Burki, K., and Hennet, T. (2008) Mol. Reprod. Dev. 75, 699-706.

53. Biellmann, F., Hulsmeier, A. J., Zhou, D., Cinelli, P., and Hennet, T. (2008) BMC Dev. Biol. 8, 109.

54. Kuan, C. T., Chang, J., Mansson, J. E., Li, J., Pegram, C., Fredman, P., McLendon, R. E., and Bigner, D. D. (2010) BMC Dev. Biol. 10, 114.

55. Brewer, C. F. (2001) Adv. Exp. Med.Biol. 491, 17-25.

56. Brewer, C. F., Miceli, M. C., and Baum, L. G. (2002) Curr. Opin. Struct. Biol. 12, 616-623.

57. Rabinovich, G. A., Toscano, M. A., Jackson, S. S., and Vasta, G. R. (2007) Curr. Opin. Struct. Biol. 17, 513-520.

58. Demetriou, M., Granovsky, M., Quaggin, S., and Dennis, J. W. (2001) Nature 409, 733-739.

59. Garner, O. B., and Baum, L. G. (2008) Biochem. Soc. Trans. 36, 1472-1477.

60. Rudd, P. M., Wormald, M. R., Stanfield, R. L., Huang, M., Mattsson, N., Speir, J. A., DiGennaro, J. A., Fetrow, J. S., Dwek, R. A., and Wilson, I. A. (1999) J. Mol. Biol. 293, 351-366.

61. Sacchettini, J. C., Baum, L. G., and Brewer, C. F. (2001) Biochemistry 40, 3009-3015.

62. Ostermeyer, A. G., Beckrich, B. T., Ivarson, K. A., Grove, K. E., and Brown, D. A. (1999) J. Biol. Chem. 274, 34459-34466.

63. Ohyama, C., Tsuboi, S., and Fukuda, M. (1999) Embo J. 18, 1516-1525.

64. Renkonen, R., Mattila, P., Majuri, M. L., Rabina, J., Toppila, S., Renkonen, J., Hirvas, L., Niittymaki, J., Turunen, J. P., Renkonen, O., and Paavonen, T. (1997) Glycoconj. J. 14, 593-600.

65. Streit, A., Yuen, C. T., Loveless, R. W., Lawson, A. M., Finne, J., Schmitz, B., Feizi, T., and Stern, C. D. (1996) J. Neurochem. 66, 834844.

66. Braccia, A., Villani, M., Immerdal, L., Niels-Christiansen, L. L., Nystrom, B. T., Hansen, G. H., and Danielsen, E. M. (2003) J. Biol. Chem. 278, 15679-15684.

67. Hsu, D. K., Chernyavsky, A. I., Chen, H. Y., Yu, L., Grando, S. A., and Liu, F. T. (2009) J. Invest. Dermatol. $129,573-583$.

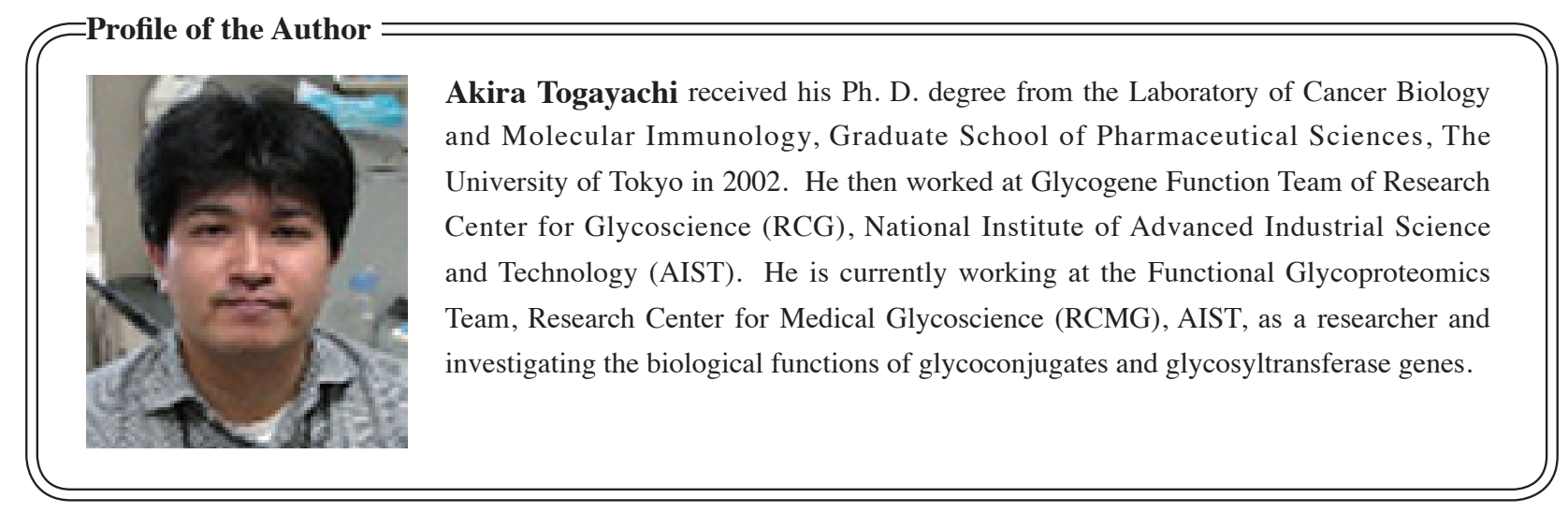

